\title{
EPSL
}

ELSEVIER

Earth and Planetary Science Letters 163 (1998) 361-379

\section{Experimentally based water budgets for dehydrating slabs and consequences for arc magma generation}

\author{
Max W. Schmidt ${ }^{\mathrm{a}, *}$, Stefano Poli ${ }^{\mathrm{b}}$ \\ ${ }^{a}$ CNRS-UMR 6524, Magmas et Volcans, 5, rue Kessler, 63038 Clermont-Ferrand, France \\ ${ }^{b}$ Dip. Scienze della Terra, Sez. Mineralogia, Via Boticelli 23, 20133 Milano, Italy
}

Received 20 February 1997; revised version received 11 May 1998; accepted 4 June 1998

\begin{abstract}
Phase diagrams of hydrous mid-ocean ridge (MOR) basalts to $330 \mathrm{~km}$ depth and of hydrous peridotites to $250 \mathrm{~km}$ depth are compiled for conditions characteristic for subduction zones. A synthesis of our experimentally determined phase relations of chlorite, lawsonite, epidote-zoisite, amphibole, paragonite, chloritoid, talc, and phengite in basalts and of phase relations from the literature of serpentine, talc, chlorite, amphibole, and phase $\mathrm{A}$ in ultramafics permits calculation of $\mathrm{H}_{2} \mathrm{O}$ contents in hydrous phase assemblages that occur in natural compositions. This yields the information necessary to calculate water budgets for descending slabs. Starting from low-grade blueschist conditions $(10-20 \mathrm{~km}$ depth) with $\mathrm{H}_{2} \mathrm{O}$ contents between 5 and $6 \mathrm{wt} \%$ for hydrated oceanic crust, complete dehydration is achieved between 70 and $>300 \mathrm{~km}$ depth as a function of individual slab geotherms. Hydrous phases which decompose at depth below volcanic arcs are lawsonite, zoisite, chloritoid, and talc ( \pm phengite) in mafic compositions and chlorite and serpentine in peridotite. Approximately $15-35 \%$ of the initially subducted $\mathrm{H}_{2} \mathrm{O}$ are released below volcanic arcs. The contribution of amphibole dehydration to the water budget is small (5-20\%) and occurs at relatively shallow depth (65-90 km). In any predicted thermal structure, dehydration is a combination of a stepwise and a continuous process through many different reactions which occur simultaneously in the different portions of the descending slab. Such a dehydration characteristic is incompatible with 'single phase dehydration models' which focus fluid flow through a unique major dehydration event in order to explain volcanic fronts. As a consequence of continuously progressing dehydration, water ascending from the slab will be generally available to depth of ca. $150-200 \mathrm{~km}$. The fluid rising from the subducting lithosphere will cause partial melting in the hot portion of the mantle wedge. We propose that the volcanic front simply forms above the mantle wedge isotherm where the extent of melting is sufficient to allow for the mechanical extraction of parental arc magmas. Thermal models show that such an isotherm $\left(\mathrm{ca} .1300^{\circ} \mathrm{C}\right)$ locates below volcanic fronts, slab surface depths below such an isotherm are compatible with the observed depths of the slab surface below volcanic fronts. () 1998 Elsevier Science B.V. All rights reserved.
\end{abstract}

Keywords: mid-ocean ridge basalts; magmas; island arcs; dehydration; slabs

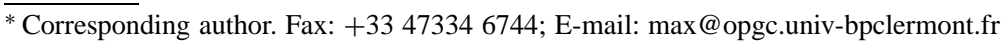




\section{Introduction}

Volcanic arcs are the most spectacular testimony of destructive plate boundaries on the Earth's surface. Volcanic fronts, i.e. the onset of arc volcanism, form in correspondence to a depth of the subducting slab between 90 and $150 \mathrm{~km}$, with a distribution maximum of $128 \pm 38 \mathrm{~km} \mathrm{[1]} \mathrm{or} 110 \pm 38 \mathrm{~km}(2 \sigma)$ [2]. The width of volcanic arcs varies between 50 and $200 \mathrm{~km}$.

It is widely accepted that arc volcanism is initiated through partial melting of a mantle wedge metasomatized by a fluid originating from dehydration of subducted crust [3-6]. The fundamental role of $\mathrm{H}_{2} \mathrm{O}$ for island arc magmatism is also documented by an average $\mathrm{H}_{2} \mathrm{O}$ content of $1.7 \mathrm{wt} \%$ in primitive island arc magmas contrasting mid-ocean ridge settings where primitive magmas have $0.1-0.5 \mathrm{wt} \%$ $\mathrm{H}_{2} \mathrm{O}$ [7].

Recent efforts in determining the stability of hydrous phases at high pressures allow us to quantify the progressive dehydration of subducting slabs. The pressure-temperature stabilities of all major hydrous phases in the principal subducted lithologies (chlorite, lawsonite, epidote/zoisite, amphibole, chloritoid, talc, and phengite in gabbros, basalts, and sediments; serpentine, chlorite, amphibole, phase A, and talc in mantle compositions) are now experimentally determined. Mass balance calculations yield the relative contributions of individual hydrous phases to the transport of $\mathrm{H}_{2} \mathrm{O}$ within the subducted lithosphere and between the subducted lithosphere and the overlying mantle wedge. The aim of this paper is to characterize and quantify the dehydration process. We present our experimental data on MOR basalt, discuss $\mathrm{H}_{2} \mathrm{O}$-saturated phase diagrams of basalt and peridotite, and compile $P-T$ diagrams of calculated wt $\%\left(\mathrm{H}_{2} \mathrm{O}\right)$ bound in hydrous phases. On the basis of these data we draw implications and discuss models for the formation of the volcanic front.

\section{Experimental procedure}

Three different basaltic compositions (Table 1) were investigated, all of them being mixtures of synthetic glasses with $\mathrm{Fe}^{3+} / \mathrm{Fe}^{\mathrm{tot}}$ ratios of $0.2-0.25$ and synthetic and natural crystal seeds $[8,9]$. LTBC
Table 1

Bulk compositions

\begin{tabular}{lccccccc}
\hline & LTBC & TB-1 & KMB-7 & MORB & hzb & lherz & pyrol \\
\hline $\mathrm{SiO}_{2}$ & 52.05 & 51.58 & 50.59 & 52.4 & 44.5 & 45.3 & 45.1 \\
$\mathrm{TiO}_{2}$ & - & 1.52 & - & 1.6 & - & - & - \\
$\mathrm{Al}_{2} \mathrm{O}_{3}$ & 16.75 & 16.68 & 18.96 & 16.9 & 1.7 & 3.6 & 3.5 \\
$\mathrm{Cr}_{2} \mathrm{O}_{3}$ & - & - & - & - & - & - & 0.4 \\
$\mathrm{Fe}_{2} \mathrm{O}_{3}$ & 2.26 & 1.83 & 1.81 & - & - & - & 0.5 \\
$\mathrm{FeO}$ & 7.41 & 8.31 & 8.24 & $10.3^{\mathrm{a}}$ & $9.6^{\mathrm{a}}$ & $7.3^{\mathrm{a}}$ & 8.0 \\
$\mathrm{MgO}$ & 7.30 & 7.02 & 6.93 & 7.1 & 42.6 & 40.3 & 37.5 \\
$\mathrm{CaO}$ & 10.01 & 9.90 & 10.08 & 10.1 & 1.4 & 3.0 & 3.1 \\
$\mathrm{Na} 2 \mathrm{O}$ & 3.18 & 3.16 & 2.90 & 3.2 & 0.1 & 0.3 & 0.6 \\
$\mathrm{~K}_{2} \mathrm{O}$ & - & - & 0.49 & 0.1 & - & - & 0.1 \\
\hline
\end{tabular}

The first three compositions are basaltic starting materials, the others averages for MOR basalt, harzburgite (hzb), lherzolite (lherz) [57] and pyrolite (pyrol) [58].

a Total iron as $\mathrm{FeO}$.

is close to a $\mathrm{Na}_{2} \mathrm{O}-\mathrm{CaO}-\mathrm{FeO}-\mathrm{MgO}-\mathrm{Al}_{2} \mathrm{O}_{3}-\mathrm{SiO}_{2}-$ $\mathrm{H}_{2} \mathrm{O}$ system, KMB contains additional $\mathrm{K}_{2} \mathrm{O}, \mathrm{TB}$ additional $\mathrm{TiO}_{2}$. Experiments contained $5 \mathrm{wt} \% \mathrm{H}_{2} \mathrm{O}$ at pressures to $40 \mathrm{kbar}$ and 2 or $1 \mathrm{wt} \% \mathrm{H}_{2} \mathrm{O}$ at higher pressures. All experiments were fluid-saturated and in piston cylinder experiments oxygen fugacity was buffered to NNO conditions by a double capsule technique.

A total of 63 experiments were performed at pressures between 18 and $120 \mathrm{kbar}$ and temperatures between 550 and $1100^{\circ} \mathrm{C}$. Run times varied from 629 $\mathrm{h}\left(18 \mathrm{GPa}, 550^{\circ} \mathrm{C}\right)$ to $30 \mathrm{~h}$ (above $800^{\circ} \mathrm{C}, 50 \mathrm{kbar}$; run table in EPSL Online Background Dataset ${ }^{1}$ ). Experiments to $36 \mathrm{kbar}$ were performed in an endloaded piston cylinder apparatus with a half-inch bore. Full salt assemblies with a tapered graphite heater were employed $[8,10]$. Experiments above 40 kbar were performed in a split sphere multi-anvil apparatus (MA-8) at the Bayerisches Geoinstitut. An 18 -mm edge length octahedra (18M) with a stepped graphite furnace was employed on an 11-mm truncation edge length (TEL) for experiments to 100 kbar and a $14 \mathrm{M}$ octahedra with a stepped $\mathrm{LaCrO}_{3}$ furnace was employed on an 8-mm TEL for experiments above $100 \mathrm{kbar}$ (for details see [11]). Thermocouples were of $\mathrm{Pt}-\mathrm{Pt}_{90} \mathrm{Rh}_{10}$ and situated in direct contact to the capsules of $1.5-2.0 \mathrm{~mm}$ ini-

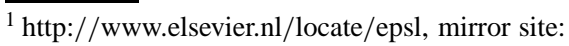
http://www.elsevier.com/locate/epsl
} 
tial length. Calibrations were against quartz-coesite, fayalite-spinel, and coesite-stishovite for the $18 \mathrm{M}$ assemblage [11] and against coesite-stishovite and $\mathrm{Mg}_{2} \mathrm{SiO}_{4}$ forsterite- $\beta$-phase at $1200^{\circ} \mathrm{C}$ for the $14 \mathrm{M}$ assemblage.

\section{MOR basalt}

\subsection{Experimental results}

Experiments between 18 and $120 \mathrm{kbar}$ and 550 and $1100^{\circ} \mathrm{C}$ of this study and experiments of previous work $[8,10]$ are compiled in Fig. 1. All experiments of this study contain garnet and omphacite, thus represent eclogitic assemblages. Several hydrous phases occur at pressures above the amphibole stability: lawsonite, zoisite, chloritoid, and occasionally talc or staurolite. In potassium-bearing basalt phengite appears ubiquitous at subsolidus conditions.

Most experiments represented in Fig. 1 were conducted with two or three different basaltic compositions (TB, KMB, and LTBC). Resulting phase assemblages for the three bulk compositions were identical with the following exceptions. The potassium-bearing basalt KMB has an additional potas-

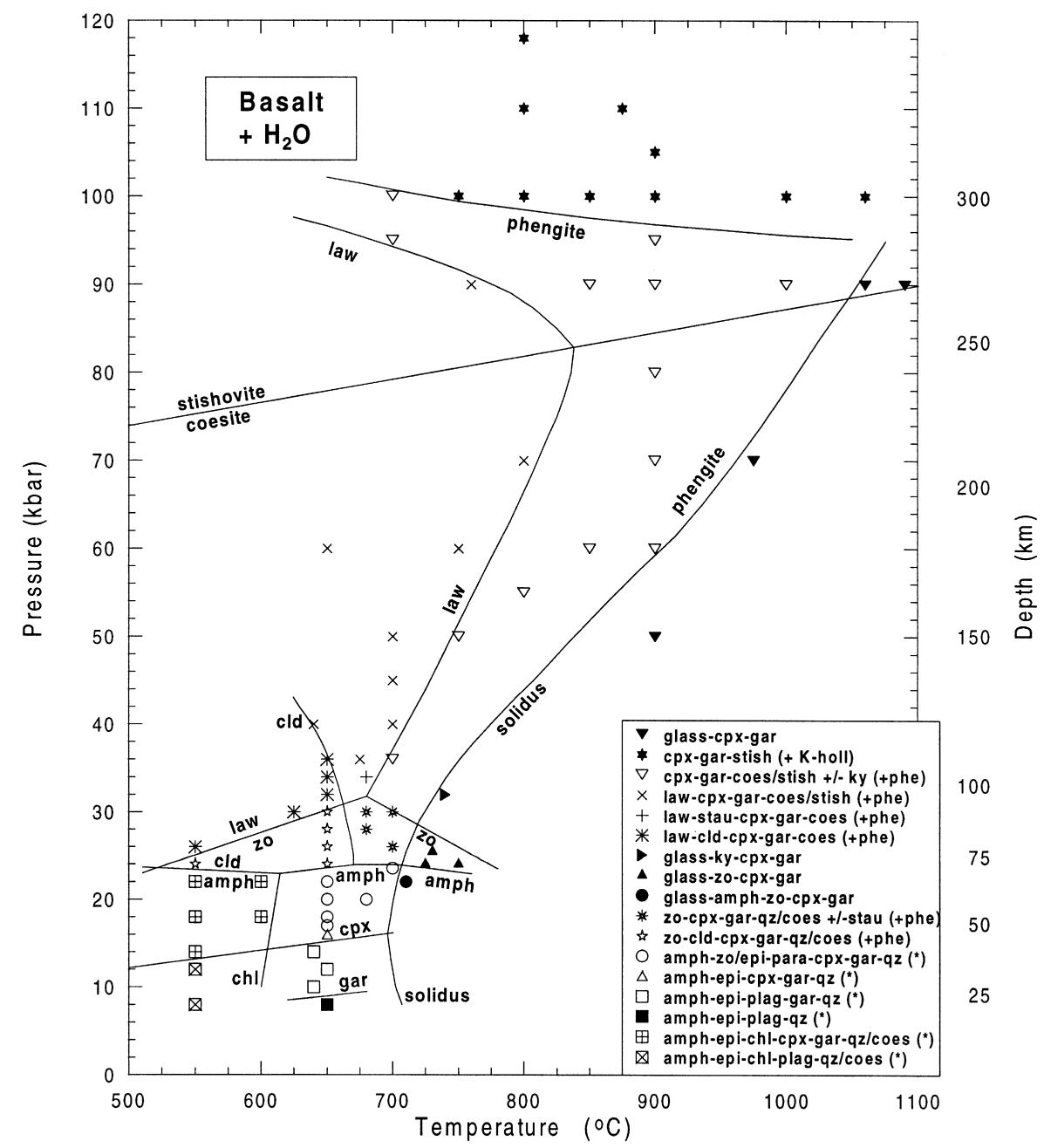

Fig. 1. Experimentally determined phase relationships for water-saturated MOR basalt: amph $=$ amphibole, $c h l=$ chlorite, $c l d=$ chloritoid, $c p x=$ jadeitic or omphacitic clinopyroxene, $e p i=$ epidote, $g a r=$ garnet, $l a w=$ lawsonite, $z o=$ zoisite. 
sium phase (phengite or K-hollandite) at subsolidus conditions. The high temperature stability of chloritoid differs for about $20-40^{\circ} \mathrm{C}$ for the different basalts. The appearance of some minor phases differs slightly between the different basalts: in LTBC talc appears in a few experiments (32-26 kbar at $650^{\circ} \mathrm{C}$ ); staurolite occurs in some experiments (preferentially in TB) between 25 and $30 \mathrm{kbar}, 650$ $700^{\circ} \mathrm{C}$; and at conditions above $30 \mathrm{kbar}, 700^{\circ} \mathrm{C} \mathrm{mi-}$ nor kyanite occurs in some experiments (LTBC and $\mathrm{KMB})$.

Clinopyroxene forms a matrix of small (3-15 $\mu \mathrm{m})$ euhedral crystals. Jadeite and diopside seeds disappeared completely and clinopyroxenes were in each experiment. Jadeite fractions are mostly between 0.40 and 0.50 but increase to $0.60-0.65$ above 90 kbar when garnets become majoritic (Table 2). At about 40 kbar, $\mathrm{K}_{2} \mathrm{O}$ contents in clinopyroxene (in $\mathrm{KMB}$ ) become significant and increase systematically with pressure to a maximum of
$1.2 \mathrm{wt} \%$ at $100 \mathrm{kbar}$ (Fig. 2). $\mathrm{K}_{2} \mathrm{O}$ contents of clinopyroxene increase with temperature until the solidus is reached but at supersolidus conditions the $\mathrm{KAlSi}_{2} \mathrm{O}_{6}$-component decreases drastically.

Garnets form texturally equilibrated crystals but often preserve cores which are intermediate between seed and rim compositions. In most experiments rims around grossular-, pyrope- or almandine-rich cores are identical in composition, but in some runs of shorter duration equilibration of rims was incomplete. Between 25 and $90 \mathrm{kbar}$ the pyrope component in garnet increases slightly. At about 90 kbar garnets become majoritic and silica contents increase to ca. $3.15 \mathrm{Si}$ per formula unit (pfu) at $110 \mathrm{kbar}$. Simultaneously, the grossular component decreases by about 15 mol\% (e.g. in KMB from gros 35 to gros 20 ).

Lawsonite crystallizes anew and forms rectangular-shaped euhedral crystals of 7-20 $\mu \mathrm{m}$ in size. Lawsonite compositions are close to endmember compositions, impurities are $0.3-0.8 \mathrm{wt} \% \mathrm{FeO}, 0.2-$

Table 2

Average phase compositions

\begin{tabular}{|c|c|c|c|c|c|c|c|c|c|c|c|c|}
\hline \multirow{4}{*}{$\begin{array}{l}P \text { (kbar): } \\
T\left({ }^{\circ} \mathrm{C}\right): \\
\text { Bulk: }\end{array}$} & \multicolumn{3}{|c|}{ Clinopyroxene } & \multicolumn{3}{|l|}{ Garnet } & \multirow{2}{*}{$\begin{array}{l}\text { Law } \\
90\end{array}$} & \multirow{2}{*}{$\begin{array}{l}\text { Zoisite } \\
30\end{array}$} & \multirow{2}{*}{$\begin{array}{l}\text { Cld } \\
32\end{array}$} & \multirow{2}{*}{$\begin{array}{l}\text { Stau } \\
26\end{array}$} & \multicolumn{2}{|c|}{ Phengite } \\
\hline & 26 & 90 & 111 & 70 & 100 & 110 & & & & & 80 & 90 \\
\hline & 700 & 850 & 870 & 900 & 900 & 800 & & 700 & 650 & 700 & 900 & 850 \\
\hline & TB & KMB & $\mathrm{TB}$ & KMB & KMB & $\mathrm{TB}$ & KMB & $\mathrm{TB}$ & TB & TB & KMB & KMB \\
\hline $\mathrm{SiO}_{2}$ & 56.10 & 54.84 & 57.50 & 40.93 & 41.29 & 41.76 & 38.42 & 39.17 & 26.37 & 29.45 & 57.45 & 59.57 \\
\hline $\mathrm{TiO}_{2}$ & 0.02 & - & 0.37 & - & - & 1.52 & - & 0.20 & 0.02 & 0.41 & - & - \\
\hline $\mathrm{Al}_{2} \mathrm{O}_{3}$ & 12.51 & 10.57 & 15.02 & 22.87 & 20.11 & 21.06 & 30.12 & 31.52 & 41.51 & 56.78 & 16.67 & 11.89 \\
\hline $\mathrm{Fe}_{2} \mathrm{O}_{3}$ & 0.00 & 0.36 & 0.45 & 0.00 & 0.49 & 0.00 & 0.14 & 2.37 & 1.64 & 0.00 & 0.00 & 0.00 \\
\hline $\mathrm{FeO}$ & 4.65 & 7.25 & 2.72 & 14.20 & 19.94 & 15.14 & 0.63 & 0.00 & 14.50 & 6.51 & 1.68 & 3.40 \\
\hline $\mathrm{MgO}$ & 8.16 & 8.58 & 6.41 & 10.12 & 10.17 & 7.50 & 0.45 & 0.04 & 8.21 & 5.83 & 7.10 & 8.72 \\
\hline $\mathrm{CaO}$ & 12.73 & 11.79 & 8.78 & 12.19 & 7.08 & 13.28 & 16.87 & 24.32 & 0.48 & 0.29 & 0.08 & 0.09 \\
\hline $\mathrm{Na}_{2} \mathrm{O}$ & 6.76 & 6.19 & 9.01 & 0.17 & 0.35 & 0.69 & 0.18 & 0.00 & 0.35 & 0.00 & 0.08 & 0.08 \\
\hline $\mathrm{K}_{2} \mathrm{O}$ & - & 0.57 & - & 0.05 & 0.20 & - & 0.02 & - & - & - & 10.84 & 10.81 \\
\hline $\mathrm{H}_{2} \mathrm{O}$ & - & - & - & - & - & - & 11.28 & 1.96 & 7.65 & 1.11 & 4.45 & 4.45 \\
\hline Total & 100.94 & 100.15 & 100.26 & 100.53 & 99.63 & 100.95 & 98.51 & 99.57 & 100.73 & 100.40 & 98.36 & 99.00 \\
\hline $\mathrm{Si}$ & 1.973 & 1.975 & 1.999 & 3.024 & 3.125 & 3.118 & 2.064 & 3.001 & 2.065 & 7.949 & 3.867 & 4.018 \\
\hline $\mathrm{Ti}$ & 0.001 & - & 0.010 & - & - & 0.085 & - & 0.012 & 0.001 & 0.083 & - & - \\
\hline $\mathrm{Al}$ & 0.519 & 0.449 & 0.615 & 1.991 & 1.794 & 1.854 & 1.887 & 2.846 & 3.831 & 18.063 & 1.322 & 0.945 \\
\hline $\mathrm{Fe}^{3+}$ & 0.000 & 0.010 & 0.012 & 0.000 & 0.028 & 0.000 & 0.005 & 0.137 & 0.097 & 0.000 & 0.000 & 0.000 \\
\hline $\mathrm{Fe}^{2+}$ & 0.137 & 0.218 & 0.079 & 0.877 & 1.262 & 0.946 & 0.028 & 0.000 & 0.949 & 1.470 & 0.095 & 0.192 \\
\hline $\mathrm{Mg}$ & 0.428 & 0.461 & 0.332 & 1.114 & 1.147 & 0.835 & 0.036 & 0.004 & 0.958 & 2.346 & 0.713 & 0.877 \\
\hline $\mathrm{Ca}$ & 0.480 & 0.455 & 0.327 & 0.965 & 0.574 & 1.063 & 0.961 & 1.996 & 0.040 & 0.084 & 0.006 & 0.007 \\
\hline $\mathrm{Na}$ & 0.461 & 0.432 & 0.607 & 0.024 & 0.052 & 0.100 & 0.018 & 0.000 & 0.054 & 0.000 & 0.010 & 0.010 \\
\hline $\mathrm{K}$ & - & 0.026 & - & 0.005 & 0.019 & - & 0.002 & - & - & - & 0.931 & 0.930 \\
\hline $\mathrm{H}$ & - & - & - & - & - & - & 4.000 & 1.000 & 4.000 & 2.000 & 2.000 & 2.000 \\
\hline
\end{tabular}

$\mathrm{Fe}^{3+}$ calculated from charge balance for lawsonite, chloritoid, and staurolite. Staurolite normalized for 15 cations and 24 oxygens including $1(\mathrm{OH})$ group. Mica formulas on 11 oxygens and $2(\mathrm{OH})$, all $\mathrm{Fe}^{2+}$. Abbrevations as in Fig. 1. 


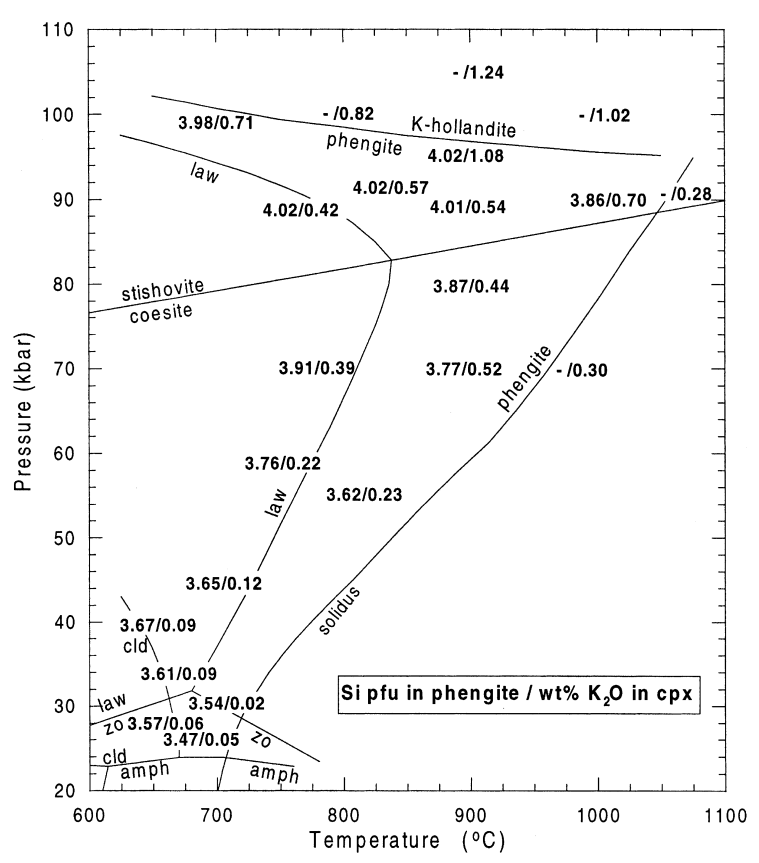

Fig. 2. Compositions of phengite (in Si per formula unit, given only in the phengite stability field) and clinopyroxene (in wt $\%$ $\mathrm{K}_{2} \mathrm{O}$ ) in MOR basalt.

$0.5 \mathrm{wt} \% \mathrm{MgO}$, and maximal $0.6 \mathrm{wt} \% \mathrm{TiO}_{2}$. Zoisite is present in all runs below $32 \mathrm{kbar}$ which do not contain lawsonite. Zoisite forms large $(15-30 \mu \mathrm{m})$ crystals which rarely preserve almost $\mathrm{Fe}$-free cores (present in the starting material). Equilibrium compositions are constant at $0.14-0.18$ Fe pfu (Table 2).

Phengite is present in all subsolidus experiments (bulk composition KMB) to $95 \mathrm{kbar}$. In most experiments, phengite tablets are larger than $15 \mu \mathrm{m}$ which allows measurement with defocused beam. Generally, the celadonite component increases with pressure and decreases slightly with temperature (Fig. 2). Around 90-95 kbar, phengite reaches an endmember celadonite composition and decomposes with further increase of pressure. In experiments above $50 \mathrm{kbar}$ with 2-3 wt $\%$ of free fluid phase, an enrichment of potassium along grain boundaries could be detected in backscatter images. However, the resolution of the microprobe did not permit to identify the origin of this enrichment. $K$-hollandite which replaces phengite towards higher pressure was extremely rare in the experimental charges. In most experiments only a few rectangular-shaped grains of 5 to $20 \mu \mathrm{m}$ with almost ideal compositions $\left(\mathrm{KAlSi}_{3} \mathrm{O}_{8}\right)$ have been found.

Chloritoid appears as aggregates of $10-40 \mu \mathrm{m}$ in size. An increase of magnesium number with temperature is observed. At pressures between 26 and $30 \mathrm{kbar}$ and at temperatures above the chloritoid stability (see Fig. 1), staurolite occurs occasionally (mostly bulk composition TB). Staurolites form small euhedral crystals of 5-10 $\mu \mathrm{m}$ size. Talc occurs in some experiments with LTBC composition. It forms relatively large crystals of 10-20 $\mu \mathrm{m}$.

Interstitial liquid forms in small amounts $(<5-$ $10 \%$ ) above the solidus; compositions could not be measured. When liquid forms, phengite and quartz/coesite/stishovite disappear. In the scanning electron microscope it appears that quenched liquids contain frequently small $(<2 \mu \mathrm{m})$ euhedral garnets and sometimes liquid is partly replaced by quench crystals of submicron size.

\subsection{Petrological evolution of subducting basalt}

Phase relationships of MOR basalt at water-saturated conditions are compiled in Figs. 1 and 3. For the low-temperature region $\left(\leq 550^{\circ} \mathrm{C}\right)$ assemblages from natural blueschists are employed. The subsolidus region below 8 kbar was experimentally investigated by Apted and Liou [12] and from 8 to 24 kbar by Poli [8]. The experiments by Pawley and Holloway [13] at pressures from 20 to $30 \mathrm{kbar}$ are consistent with our experiments.

During subduction, the oceanic crust passes through a blueschist facies stage (10-50 km depth). Natural blueschists of basaltic origin are mostly fully hydrated while coarse-grained gabbros [14] often show domainal equilibria resulting from uneven water distribution. A general sequence of hydrous phases in basalt with increasing pressure might be described as follows. At blueschist conditions, assemblages are typically composed of lawsonite-glaucophane-chlorite-albite/jadeite \pm phengite (fields $G$ and K, Fig. 3). With increasing temperature lawsonite reacts to epidote/zoisite (fields F, I, and J), chlorite decomposes forming mainly garnet (fields $\mathrm{E}$ and $\mathrm{H}$ ), and glaucophane changes composition to barrositic amphibole. At temperatures above $600^{\circ} \mathrm{C}$, pressures from 15 to 22 kbar, an amphibole-eclogite results (field E). When 


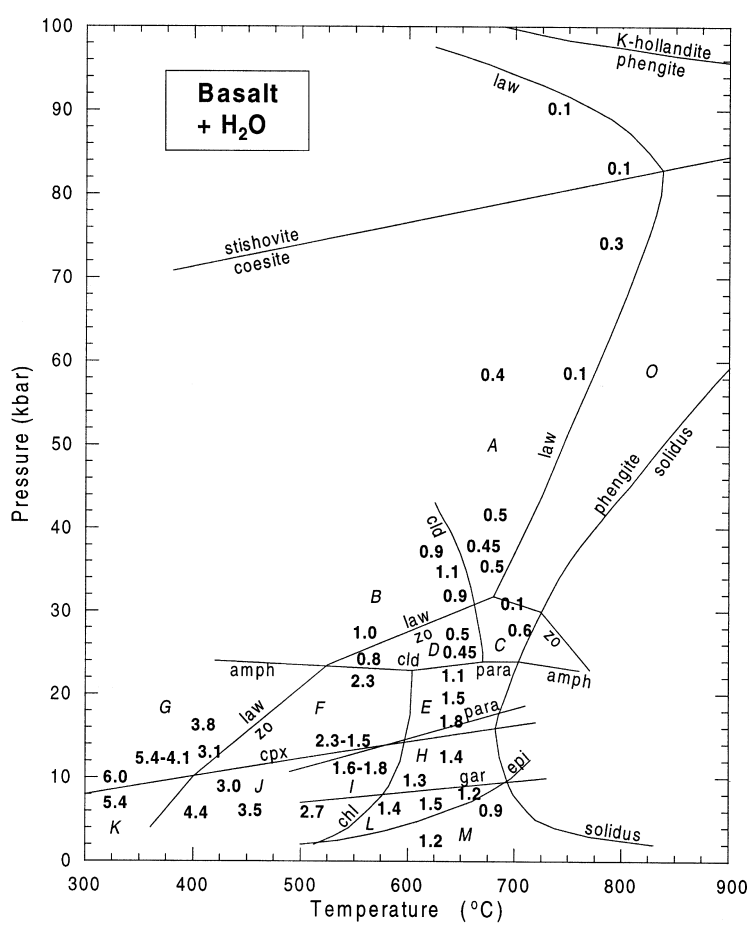

Fig. 3. Maximum $\mathrm{H}_{2} \mathrm{O}$ contents bound in hydrous phases in $\mathrm{H}_{2} \mathrm{O}$-saturated MOR basalt. For assemblages and references see Table 3.

pressure oversteps 22-24 kbar, amphiboles decompose forming chloritoid at temperatures below $660^{\circ} \mathrm{C}$ (fields B and D). Blueschists transform to lawsoniteeclogites (fields A and B) and amphibole-eclogites to zoisite-eclogite (fields $\mathrm{C}$ and D). At ca. $30 \mathrm{kbar}$ zoisite reaches its maximum stability in metabasalts (at $f_{\mathrm{O}_{2}}=\mathrm{NNO}$ ), its breakdown leaves an almost dry eclogite at conditions above $30 \mathrm{kbar}, 700^{\circ} \mathrm{C}$ (field $\mathrm{O})$. At lower temperatures, lawsonite persists reaching its maximum temperature stability at $830^{\circ} \mathrm{C}, 84$ kbar (field A). If potassium is present in a subducted MOR basalt, phengite forms ubiquitously to pressures of $100 \mathrm{kbar}$ [9]. The presence of phengite also determines minimum melting conditions of MOR basalts at high pressures.

Other minor hydrous phases in MOR basalt are paragonite, talc, and staurolite. Paragonite forms at $12-16 \mathrm{kbar}\left(\right.$ at $500-650^{\circ} \mathrm{C}$ ) and decomposes around $22 \mathrm{kbar}\left(500-700^{\circ} \mathrm{C}\right.$, field $\mathrm{E}$ and part of field $\left.\mathrm{F}\right)$. The conditions of talc and staurolite occurrence are relatively restricted, although talc is probably an important high-pressure phase in $\mathrm{Mg}$-gabbros.
Most of the reactions involved are discussed by $[8,10]$. We complete the discussion of phase relations with the lawsonite and phengite breakdown reactions at high pressures. At pressures above the zoisite stability, lawsonite decomposes through a continuous reaction of the type

$$
\begin{aligned}
& \text { lawsonite }+ \text { diopside }+ \text { garnet }_{1} \\
& \quad=\text { garnet }_{2}+\text { coesite/ stishovite }+\mathrm{H}_{2} \mathrm{O}
\end{aligned}
$$

where garnet ${ }_{2}$ is richer in grossular and pyrope component than garnet $_{1}$. In the coesite stability field, this reaction has a positive $\Delta V$ and a positive $\mathrm{d} P / \mathrm{d} T$ slope which steepens with increasing pressure (Fig. 1). When stishovite replaces coesite, $\Delta V$ of reaction becomes negative. Thus, above $80 \mathrm{kbar}$, reaction (1) has a negative $\mathrm{d} P / \mathrm{d} T$ slope and thus limits the maximum pressure stability of lawsonite in subduction zones to 80-90 kbar.

White mica, the principal potassium host in natural blueschists and eclogites, decomposes through a continuous and a discontinuous reaction. At pressures above $40 \mathrm{kbar}$, a significant solubility of potassium in clinopyroxene is observed and phengite decomposes forming $\mathrm{KAlSi}_{2} \mathrm{O}_{6}-\mathrm{cpx}+$ enstatite + coesite $+\mathrm{K}$-rich fluid [9]. This reaction is continuously progressing from $40 \mathrm{kbar}$ until the terminal phengite stability near $100 \mathrm{kbar}$ is reached. The discontinuous breakdown of phengite to K-hollandite $\left(\mathrm{KAlSi}_{3} \mathrm{O}_{8}\right)$ + clinopyroxene $+\mathrm{K}$-rich fluid and the related dehydration might be of small significance in basaltic compositions. Mass balance calculations on the basis of the experiments reveal that in MOR basalts $\left(0.1-0.5 \mathrm{wt} \% \mathrm{~K}_{2} \mathrm{O}\right)$ phengite may react completely to $\mathrm{K}-\mathrm{cpx}$ before the pressure stability of phengite is reached (Fig. 4). With a potassium solubility in clinopyroxene of about $1 \mathrm{wt} \%$ (at $100 \mathrm{kbar}$ ) and a modal amount of 40-50 wt $\%$ cpx, $0.4-0.5 \mathrm{wt} \%$ bulk- $\mathrm{K}_{2} \mathrm{O}$ can be stored in clinopyroxene.

\subsection{Mass balance}

Modal amounts of phases in basalt (Table 3) are compiled from natural blueschists with basaltic chemistry [15-19], from [12] and from our own experiments. For a description of modal amount calculations in basalt see [8]. Fig. 3 gives wt $\%$ of $\mathrm{H}_{2} \mathrm{O}$ in the bulk rock bound in hydrous phases. These 


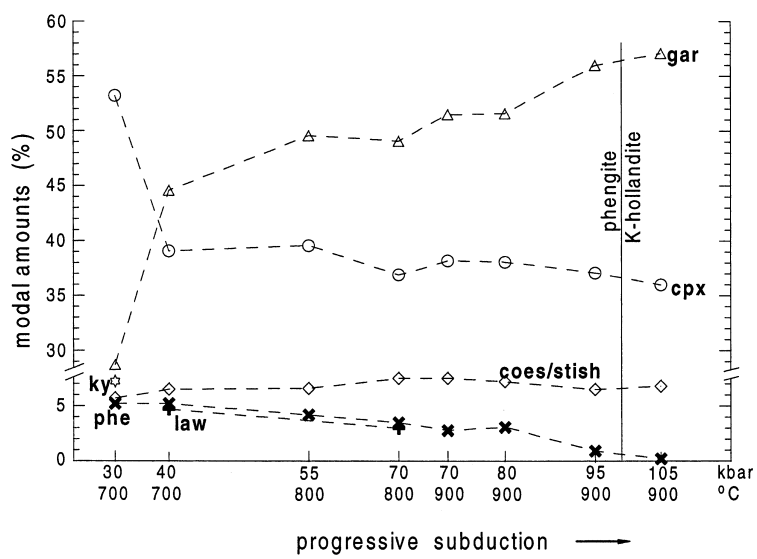

Fig. 4. Modal amounts of phases in MOR basalt with $0.5 \mathrm{wt} \%$ $\mathrm{K}_{2} \mathrm{O}$ along a typical subduction geotherm. Phengite continuously decomposes when potassium solubility in clinopyroxene increases.

values are for potassium-free basalt. For potassiumbearing basalt $0.5 \mathrm{wt} \% \mathrm{H}_{2} \mathrm{O}$ (equivalent to $8-9 \mathrm{wt} \%$ phengite) must be added per $1 \mathrm{wt} \% \mathrm{~K}_{2} \mathrm{O}$. Our results are comparable to those of [20] which estimated water contents for subducting oceanic crust to $40 \mathrm{~km}$ depth.

As can be seen from Fig. 3, many different reactions involving hydrous phases modify the water contents during the transition from blueschists to dry eclogites. Water contents will continuously decrease because most of the reactions are continuous reactions involving solid solutions and thus take place over a temperature/pressure interval [21]. In an experimental study [8] it was shown that continuous amphibole decomposition in amphibole eclogite (field $\mathrm{H}$ and $\mathrm{E}$ in Fig. 3) causes as much dehydration as the final amphibole breakdown (each $\Delta \mathrm{H}_{2} \mathrm{O}^{\text {tot }}=0.6 \mathrm{wt} \%$ ).

The phases with large contributions to the water budget of subducting MOR basalt are lawsonite, chlorite, and amphibole (glaucophane or barroisite in composition). Lawsonite contains $11.2 \mathrm{wt} \% \mathrm{H}_{2} \mathrm{O}$ and typically amounts to 7-15 wt \% . Chlorite in basalt contains about $12 \mathrm{wt} \% \mathrm{H}_{2} \mathrm{O}$ and amounts to $5-30 \mathrm{wt} \%$. Amphibole only contains $2.1 \mathrm{wt} \% \mathrm{H}_{2} \mathrm{O}$ but forms 20-60 wt\% of a basalt. Other significant contributions arise from epidote/zoisite (1.95 wt $\% \mathrm{H}_{2} \mathrm{O}$ ) which forms typically 5-20 wt $\%$, and from chloritoid $\left(7.5 \mathrm{wt} \% \mathrm{H}_{2} \mathrm{O}\right)$ amounting to $3-$ $8 \mathrm{wt} \%$. Paragonite $\left(4.6 \mathrm{wt} \% \mathrm{H}_{2} \mathrm{O}\right)$, talc $(4.8 \mathrm{wt} \%$ $\left.\mathrm{H}_{2} \mathrm{O}\right)$, and staurolite $\left(1.0 \mathrm{wt} \% \mathrm{H}_{2} \mathrm{O}\right)$ have only minor contributions due to medium-low water contents in combination with relatively low modal abundances.

The following dehydration characteristics can be defined. In the shallow portion of the subducting slab, basalts typically contain 5-6 wt $\% \mathrm{H}_{2} \mathrm{O}$. With increasing pressure (but still in the stability field of amphibole), water contents decrease to ca. 3 $\mathrm{wt} \%$ at low temperatures where lawsonite + chlorite + glaucophane is stable, to $2.0-2.5 \mathrm{wt} \%$ at intermediate temperatures where epidote + chlorite + glaucophane/barroisite is stable, and to 1-1.5 $\mathrm{wt} \%$ where epidote/zoisite + barroisite is stable.

Table 3

Assemblages, modal amounts of hydrous phases (wt $\%$ ) and $\mathrm{H}_{2} \mathrm{O}$ (wt $\%$ ) bound in hydrous phases in MOR basalt

\begin{tabular}{lllll}
\hline Field in Fig. 3 & Assemblage & Ranges for modal amounts of hydrous phases & ${\text { Range of } \mathrm{H}_{2} \mathrm{O}^{\text {tot }}}^{\text {References }}$ \\
\hline$O$ & gar-cpx-coes/stish & - & 0.0 & \\
$A$ & law-gar-cpx-coes/stish & $1-5$ law & $0.1-0.5$ & {$[10]$, this study } \\
$B$ & law-cld-gar-cpx-qz/coes & $4-7$ law, 4-10 cld & $0.9-1.1$ & {$[10]$, this study } \\
$C$ & zo-gar-cpx-qz/coes & $1-4$ zo; $(13$ zo, 8 tc) & $0.1-0.6$ & this study, ([19]) \\
$D$ & zo-cld-gar-cpx-qz/coes & $3-5$ zo, 5-9 cld & $0.5-0.8$ & {$[8]$, this study } \\
$E$ & amph-zo/epi-para-gar-cpx-qz & $22-60$ amph, 16-20 epi, 4-6 para & $1.1-1.8$ & {$[8]$} \\
$F$ & amph-zo-chl-t para-gar-cpx-qz & $22-48$ amph, 9-22 epi, 4-12 chl, 0-5 para & $1.5-2.3$ & {$[8,17]$} \\
$G$ & law-chl-glauc-gar-cpx-qz & $35-45$ amph, 22-36 law, 0-13 chl & $3.1-6.0$ & {$[10]^{\mathrm{a}},[15]$} \\
$H$ & amph-epi-plag-gar-qz & $45-58$ amph, 9-14 epi & $1.2-1.4$ & {$[8,16]$} \\
$I$ & amph-epi-chl-plag-gar-qz & $25-26$ amph, 7-11 epi, 8-9 chl & $1.6-1.8$ & {$[17]$} \\
$J$ & amph-epi-chl-ab/plag-qz & $12-35$ amph, 15-30 chl, 25-34 epi & $2.7-4.4$ & {$[12,18]$} \\
$K$ & law-amph-chl-ab-qz & 58 amph, 34 law, 4 chl & 5.4 & {$[10]^{\mathrm{a}}$} \\
$L$ & epi-amph-plag-qz & $39-62 \mathrm{amph}, 8-30$ epi & $1.2-1.5$ & {$[8,12,16]$} \\
$M$ & amph-plag-qz & $45-60$ amph & $0.9-1.2$ & {$[12]$} \\
\hline
\end{tabular}

${ }^{a}$ [10]: references in Ref. [10], Ref. [19] is from a coesite bearing gabbro. 
The most significant discontinuous reactions in the amphibole stability field are the formation of omphacitic clinopyroxene and the breakdown of chlorite. At pressures exceeding the stability of amphibole ( $>22-24 \mathrm{kbar}$ ), ca. $1 \mathrm{wt} \% \mathrm{H}_{2} \mathrm{O}$ remain bound in lawsonite and chloritoid $\left(<520^{\circ} \mathrm{C}\right)$ and $0.5-0.7$ wt $\% \mathrm{H}_{2} \mathrm{O}$ bound in zoisite \pm chloritoid. At higher pressures (>30-40 kbar) when lawsonite constitutes the only non-potassic hydrous phase, the bulk water content is typically $0.2-0.5 \mathrm{wt} \% \mathrm{H}_{2} \mathrm{O}$.

Apart from the continuity of several reactions, temperature gradients and compositional variations in the descending oceanic crust will further broaden the dehydration signal. Temperature gradients within a $7-10 \mathrm{~km}$ thick oceanic crust are $100-300^{\circ} \mathrm{C}$ [22]. Consequently, several dehydration reactions may take place at the same depth. Strictly, these calculations and phase relationships are only valid for MOR basaltic compositions. However, the stabilities of lawsonite, epidote/zoisite, amphibole, and chlorite are relatively insensitive to bulk rock composition [10]. On the contrary, ferromagnesian phases such as chloritoid and talc will have significantly enlarged stability fields and abundances in Mg-gabbros as can be deduced from field occurrences ([23] and references therein).

\section{Metapelites and metagreywackes}

Metapelites and metagreywackes constitute on average the upper $10 \%$ of the oceanic crust. Although they contribute only a small portion to the water budget, they are important for hosting the vast amount of certain elements or isotopes characteristic for the sediment-signature in arc magmas $(\mathrm{K}, \mathrm{Rb}, \mathrm{Ba}, \mathrm{Sr}$,

${ }^{10} \mathrm{Be}$, enrichment in $\left.{ }^{207} \mathrm{~Pb}[3,5,6]\right)$. Phase relations for sedimentary materials metamorphosed at subduction zone conditions were experimentally studied by [24-26].

Chlorite + kyanite and staurolite + quartz are limited to pressures below $20 \mathrm{kbar}$ for most natural bulk compositions, the latter having $\mathrm{Mg} /(\mathrm{Mg}+\mathrm{Fe})$ ratios of 0.3-0.6. At pressures above $20 \mathrm{kbar}$, hydrous assemblages comprise talc-chloritoid-phengite or talc-phlogopitephengite. Between 40 and 50 kbar talc + kyanite destabilizes and $\mathrm{Mg}-\mathrm{Al}$-pumpellyite $(7.1 \mathrm{wt} \%$
$\left.\mathrm{H}_{2} \mathrm{O}\right)$ and/or topaz-OH $\left(10.7 \mathrm{wt} \% \mathrm{H}_{2} \mathrm{O}\right)$ might form in the presence of phengite. Metagreywackes are commonly richer in $\mathrm{Ca}$ than metapelites and thus lawsonite or zoisite are more abundant. The stability field of lawsonite in metapelite [26] is very similar to that in mafic systems. $\mathrm{H}_{2} \mathrm{O}$ storage in sediments to more than $200 \mathrm{~km}$ depth is ensured by phengite, lawsonite, $\mathrm{MgAl}-$ pumpellyite, and topaz-OH at temperatures as high as $900^{\circ} \mathrm{C}$.

\section{Peridotites}

The principal hydrous phases in $\mathrm{H}_{2} \mathrm{O}$-saturated peridotite to $80 \mathrm{kbar}$ are serpentine, phase A, chlorite, talc, and amphibole. Stabilities of serpentine, phase A, and talc are expected to be almost identical for depleted or fertile peridotite because these phases are almost $\mathrm{Ca}$ - and $\mathrm{Na}$-free and contain only minor amounts of $\mathrm{Al}_{2} \mathrm{O}_{3}$. Their stabilities have been experimentally determined on natural mineral compositions [27,28]. The stabilities of chlorite and amphibole are expected to vary for harzburgitic, lherzolitic, and pyrolitic bulk compositions. Mysen and Boettcher [29] determined a stability increase of amphibole from ca. $22 \mathrm{kbar}$ in harzburgite to ca. $25 \mathrm{kbar}$ in enriched lherzolite (at $800-1000^{\circ} \mathrm{C}$ ).

Serpentine contains $12.3 \mathrm{wt} \% \mathrm{H}_{2} \mathrm{O}$ and dominates, together with chlorite $\left(13.0 \mathrm{wt} \% \mathrm{H}_{2} \mathrm{O}\right)$, the water budget of hydrous peridotite to ca. $150 \mathrm{~km}$ depth. In natural peridotites serpentine forms during low-grade hydration, and its maximum temperature stability is $720^{\circ} \mathrm{C}(21 \mathrm{kbar}$, invariant point 3 in Fig. 5). Serpentine (antigorite, $\mathrm{Mg}_{48} \mathrm{Si}_{34} \mathrm{O}_{85}(\mathrm{OH})_{62}$ ) decomposes to talc + olivine $+\mathrm{H}_{2} \mathrm{O}$ below 21 kbar [27], to orthopyroxeneolivine $+\mathrm{H}_{2} \mathrm{O}$ from 21 to 62 kbar, and to phase $\mathrm{A}+$ orthopyroxene $+\mathrm{H}_{2} \mathrm{O}$ [28] at higher pressures (invariant point 4 in Fig. 5).

In average mantle compositions, talc (4.7 wt $\%$ $\left.\mathrm{H}_{2} \mathrm{O}\right)+$ olivine have a rather limited stability field less than $100^{\circ} \mathrm{C}$ wide, and they decompose to enstatite $+\mathrm{H}_{2} \mathrm{O}$ between $690^{\circ} \mathrm{C}(10 \mathrm{kbar})$ and $720^{\circ} \mathrm{C}$ (20 kbar) [28]. In relatively silica-rich veins, talc might locally persist to higher temperatures and pressures [30,31].

In subducted peridotite, phase $A$ $\left(\mathrm{Mg}_{7} \mathrm{Si}_{2} \mathrm{O}_{8}(\mathrm{OH})_{6}, 11.8 \mathrm{wt} \% \mathrm{H}_{2} \mathrm{O}\right)$ replaces serpentine at pressures between 60 and 70 kbar through 


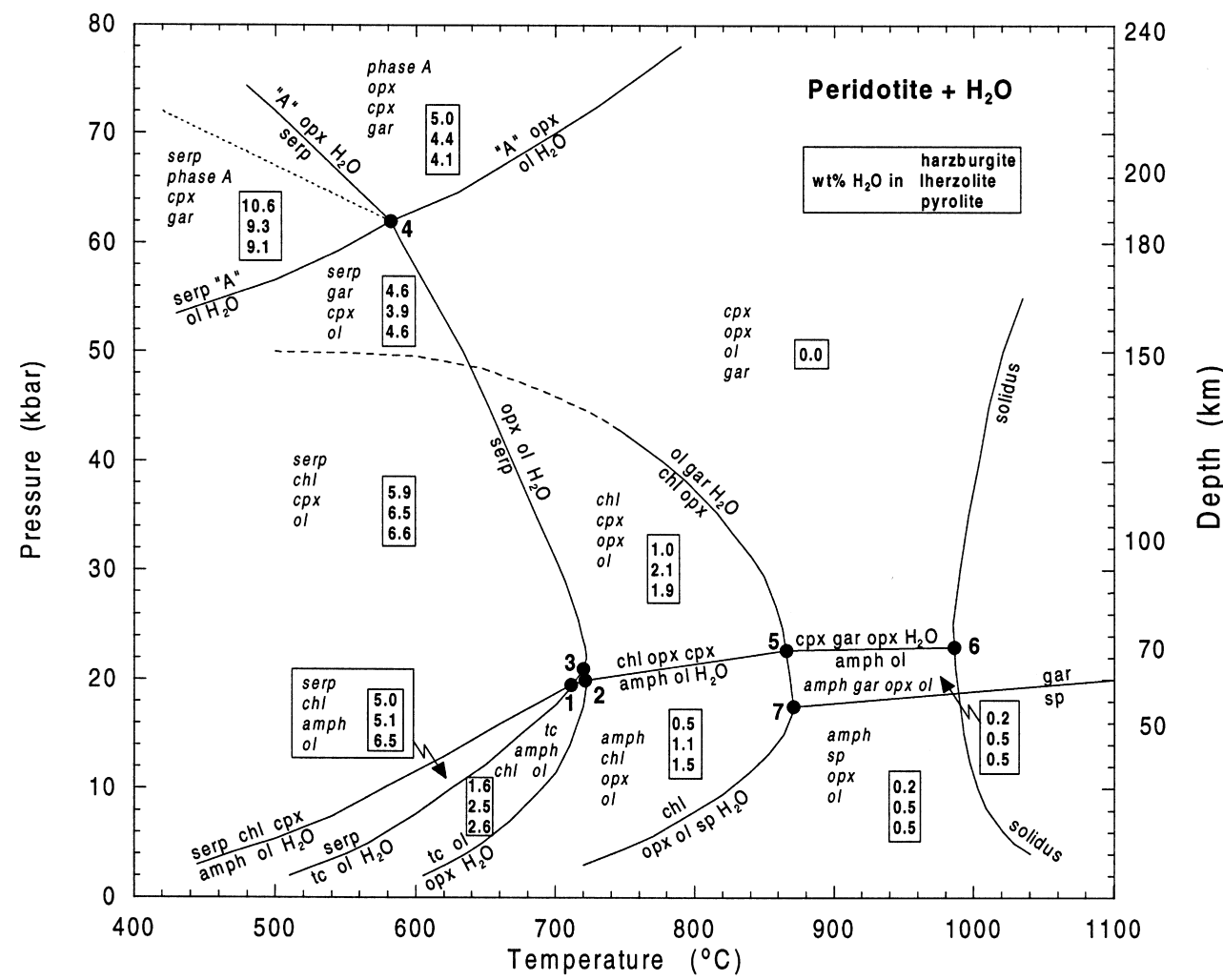

Fig. 5. Phase diagram for $\mathrm{H}_{2} \mathrm{O}$-saturated average mantle peridotite and maximum $\mathrm{H}_{2} \mathrm{O}$ contents bound in hydrous phases in average peridotites. Upper value: harzburgite; middle value: lherzolite; lower value: pyrolite. The italic labels are assemblages in a given stability field. ' $A$ ' = phase A, amph = amphibole, $c h l=$ chlorite, $c p x=$ clinopyroxene, $g a r=$ garnet, $o l=$ olivine, opx $=$ orthopyroxene, $\operatorname{serp}=$ serpentine, $s p=$ spinel, $t c=$ talc.

a water-conserving reaction (dotted line emerging from invariant point 4 in Fig. 5). Although phase A could form at lower pressures through olivine $+\mathrm{H}_{2} \mathrm{O}$ $=$ phase $\mathrm{A}+$ serpentine, the free water necessary for this reaction would not be available in subducting peridotite. Above $62 \mathrm{kbar}$, phase A + orthopyroxene decompose with increasing temperature to enstatite $+\mathrm{H}_{2} \mathrm{O}$. This reaction has a moderate positive slope in $P-T$ space [32].

In natural peridotites, chlorites have compositions close to clinochlor $\left(\mathrm{Mg}_{5} \mathrm{Al}_{2} \mathrm{Si}_{3} \mathrm{O}_{10}(\mathrm{OH})_{8}\right)$. Synthetic clinochlor decomposes between 3 and $21 \mathrm{kbar}$ to olivine + orthopyroxene + spinel $+\mathrm{H}_{2} \mathrm{O}$ with a maximum temperature stability of $870^{\circ} \mathrm{C}$ ([31] and references therein). Above $21 \mathrm{kbar}$, the occurrence of chlorite in peridotite is limited through the reaction chlorite + orthopyroxene $=$ olivine + garnet + $\mathrm{H}_{2} \mathrm{O}$. This reaction was experimentally determined to pressures of $40 \mathrm{kbar}$ [33]. Although considerable uncertainty remains, it can be deduced from experiments on the terminal stability of chlorite [34] that the stability of chlorite + orthopyroxene do not exceed 50 kbar. The stability of chlorite outlined in Fig. 5 represents probably a maximum, and Fe could decrease the stability of chlorite in natural peridotite significantly.

\subsection{Amphibole in peridotite}

A compilation of all experimental studies on amphibole in water-saturated peridotite compositions yields the following picture. Close to the water-saturated solidus (approximately $1000^{\circ} \mathrm{C}$, at $20-30 \mathrm{kbar}$ ), amphibole is pargasitic hornblende in composition and decomposes between 22 and 30 kbar. In harzburgite, calcic amphibole decomposes at $22 \mathrm{kbar}$, in lherzolite at 25-28 kbar and in enriched pyrolite at 28-30 kbar [29,35-37]. Mysen and Boettcher 


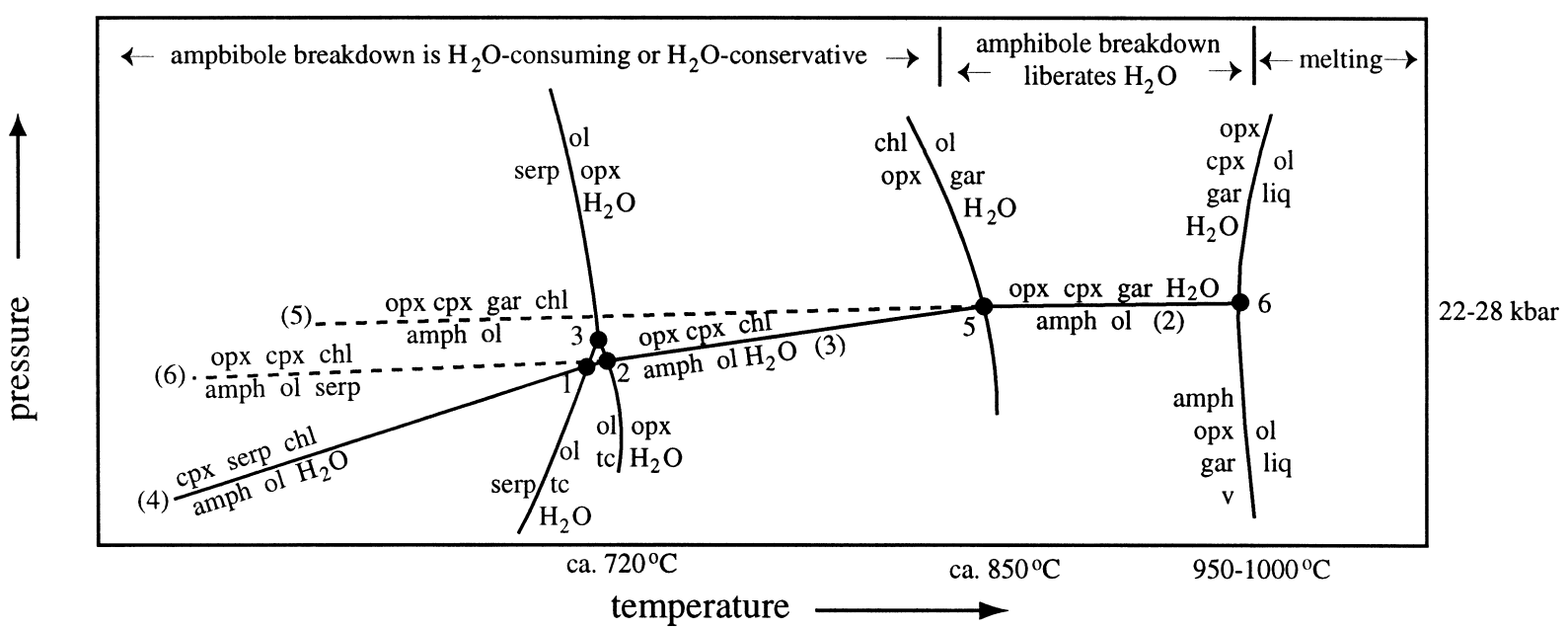

Fig. 6. Result of Schreinemaker analysis for breakdown reactions of amphibole in peridotite. The solid lines are amphibole breakdown reactions in a system where excess water is present, the stippled lines represent amphibole breakdown reactions in a fluid-absent system. The highest pressure where amphibole is stable is located at the solidus. Numbers without parentheses refer to invariant points in Fig. 5. The amphibole breakdown reaction between invariant point 1 and 2 is amph $+\mathrm{ol}+\mathrm{H}_{2} \mathrm{O}=\mathrm{tc}+\mathrm{cpx}+\mathrm{chl}$. Abbreviations as in Fig. 5 .

[29] determined experimentally a slightly positive $P-T$ slope for the amphibole-out reaction at subsolidus conditions. Calculations of the $P-T$ slope of the amphibole-out reaction (2) of Fig. 6 agree with [29] yielding 3 to $-1 \mathrm{bar} / \mathrm{K}$ as a function of exact amphibole-composition and solid solution model (molar volumes and entropies from 1996 update of [38]). Consequently, the highest pressure stability of amphibole is located at the intersection of the amphibole-out curve with the solidus, i.e. between 22 and $30 \mathrm{kbar}$ (65-90 km depth). With decreasing temperature, this pressure is reduced by several kbar (Figs. 5 and 6). The experimental evidence is in sharp contrast to Tatsumi [2] who extrapolates the slope of Millholen et al.'s [35] amphibole melting curve into the subsolidus in order to reach $35 \mathrm{kbar}$ at $700^{\circ} \mathrm{C}$. The amphibole-out reaction near the solidus does not shift as a function of the bulk $\mathrm{H}_{2} \mathrm{O}$ content: as long as the volatile species is only water, reaction (2) of Fig. 6 does not change position in $P-T$ space. When the fluid is diluted by components other than $\mathrm{H}_{2} \mathrm{O}$, this reaction is shifted to lower pressures, consequently, $\mathrm{H}_{2} \mathrm{O}$-saturated bulk compositions yield the highest amphibole stabilities.

At temperatures where chlorite appears instead of garnet, reaction (2) transforms into reaction (3) (Fig. 6). Calculated $P-T$ slopes for the latter reaction are positive and range from 11 to $13 \mathrm{bar} / \mathrm{K}$. The amphibole breakdown reactions (3) and (4), latter in the chlorite + serpentine stability field, do not liberate water. On the contrary, in a water-saturated system, the decomposition of amphibole consumes water with increasing pressure. In the descending slab, additional water is not necessarily available and amphibole decomposes through water conserving reactions (5) and (6) (Fig. 6). Thus, it is only at temperatures above the chlorite stability that the amphibole breakdown liberates water.

The exact stoichiometries of the amphibole decomposition reactions are complicated by the change of amphibole composition with temperature. From experiments and natural xenoliths it is known that at temperatures near the solidus amphibole is pargasitic hornblende in composition. In low temperature-high pressure metamorphic peridotites, amphiboles are aluminous tremolites. For the pressure breakdown reactions we thus continuously interpolated between these two amphibole compositions. Fig. 6 is valid for amphibole compositions to be expected in natural peridotite; however, reaction topologies are different for endmembers such as tremolite or edenite.

\subsection{Water contents in fully hydrated peridotite}

Modal abundances in hydrous peridotite assemblages are calculated employing a least-square 
Table 4

Modal amounts (wt\%) and maximum $\mathrm{H}_{2} \mathrm{O}$ contents (wt \%) bound in hydrous phases in hydrous peridotites

\begin{tabular}{|c|c|c|c|c|c|c|c|c|c|c|c|}
\hline \multirow{2}{*}{$\begin{array}{l}\text { Assemblage } \\
\text { serp-chl-cpx-ol }\end{array}$} & \multicolumn{4}{|c|}{$\begin{array}{l}\text { Herzolite } \\
\text { solid phases }\end{array}$} & \multirow{2}{*}{$\begin{array}{l}\text { Lherzolite } \\
\mathrm{H}_{2} \mathrm{O}^{\text {tot }} \\
6.5\end{array}$} & \multirow{2}{*}{$\begin{array}{l}\begin{array}{l}\text { Pyrolite } \\
\mathrm{H}_{2} \mathrm{O}^{\text {tot }}\end{array} \\
6.6\end{array}$} & \multicolumn{4}{|c|}{$\begin{array}{l}\text { Harzburgite } \\
\text { solid phases }\end{array}$} & \multirow{2}{*}{$\frac{\begin{array}{l}\text { Harzburgite } \\
\mathrm{H}_{2} \mathrm{O}^{\text {tot }}\end{array}}{5.9}$} \\
\hline & 37.9 & 15.7 & 13.4 & 33.0 & & & 41.0 & 7.8 & 6.1 & 45.1 & \\
\hline serp-gar-cpx-ol & 32.3 & 11.9 & 10.6 & 45.3 & 3.9 & 4.3 & 38.4 & 5.9 & 4.6 & 51.2 & 4.6 \\
\hline serp-gar-cpx-phase A & 59.2 & 11.2 & 10.0 & 19.6 & 9.3 & 9.1 & 68.2 & 5.5 & 4.3 & 22.1 & 10.6 \\
\hline phase A-gar-cpx-opx & 38.4 & 11.8 & 10.5 & 39.2 & 4.4 & 4.1 & 44.1 & 5.8 & 4.6 & 45.5 & 5.0 \\
\hline serp-chl-amph-ol & 25.8 & 12.2 & 21.2 & 40.7 & 5.1 & 6.4 & 33.9 & 6.2 & 9.9 & 50.0 & 5.0 \\
\hline talc-chl-amph-ol & 8.9 & 12.5 & 21.8 & 56.8 & 2.5 & 2.6 & 11.7 & 6.4 & 10.3 & 71.7 & 1.6 \\
\hline opx-chl-amph-ol & 14.7 & 5.1 & 22.1 & 58.1 & 1.1 & 1.5 & 17.2 & 2.5 & 10.4 & 69.9 & 0.5 \\
\hline opx-chl-cpx-ol & 17.4 & 16.4 & 14.0 & 51.9 & 2.1 & 1.9 & 19.1 & 8.2 & 6.4 & 66.3 & 1.0 \\
\hline opx-sp-amph-ol & 16.7 & 0.2 & 22.2 & 61.0 & 0.5 & 0.5 & 18.1 & 0.1 & 10.4 & 71.4 & 0.2 \\
\hline opx-gar-amph-ol & 16.0 & 1.7 & 21.3 & 60.9 & 0.5 & 0.5 & 17.7 & 1.1 & 9.9 & 71.4 & 0.2 \\
\hline opx-gar-cpx-ol & 15.7 & 13.0 & 10.3 & 61.0 & 0.0 & 0.5 & 18.1 & 6.4 & 4.6 & 71.0 & 0.0 \\
\hline
\end{tabular}

fit procedure. $\mathrm{FeO}+\mathrm{MgO}, \mathrm{Al}_{2} \mathrm{O}_{3}+\mathrm{Fe}_{2} \mathrm{O}_{3}$ $+\mathrm{Cr}_{2} \mathrm{O}_{3}$, and $\mathrm{Na}_{2} \mathrm{O}+\mathrm{K}_{2} \mathrm{O}$ were each reduced to a single chemical component. Serpentine and chlorite compositions were held constant at the ideal stoichiometries of antigorite and clinochlor. This introduces a small error for the calculated abundances of chlorite. By varying the alumina content of clinochlor for $\pm 20 \%$, relative differences in the calculated $\mathrm{H}_{2} \mathrm{O}^{\text {tot }}$ contents are $-11 /+16 \%$ for the assemblage chloriteamphibole-orthopyroxene-olivine and $-17 /+26 \%$ for chlorite-clinopyroxene-orthopyroxene-olivine. Amphibole compositions were varied with temperature as described above. The relative amounts of clinopyroxene and amphibole depend on their $\mathrm{Na}$ : Ca ratios. Since compositional data at low temperatures are scarce, we allowed amphibole to completely replace clinopyroxene. This results in maximum amphibole and minimum chlorite abundances.

The results of the mass balance calculations for average peridotite compositions (Table 1) are presented in Table 4 and Fig. 5. In the stability fields of serpentine and phase $\mathrm{A}$ the total amount of $\mathrm{H}_{2} \mathrm{O}$ bound in hydrous phases varies between 3.9 and 10.6 wt $\%$ of the bulk rock. In the stability field of serpentine + chlorite + amphibole, chlorite contributes approximately $30 \%$ (lherzolite) of the $\mathrm{H}_{2} \mathrm{O}$ bound in hydrous phases, whereas amphibole contributes less than $10 \%$ (Table 4). When serpentine reacts to talc, $\mathrm{H}_{2} \mathrm{O}$ contents decrease from 5.1 to $2.5 \mathrm{wt} \%$ in lherzolite. At higher temperatures, when chlorite + amphibole constitute the stable hydrous phases,
$\mathrm{H}_{2} \mathrm{O}$ contents decrease to $1.1 \mathrm{wt} \%$ in lherzolite $(0.5$ wt $\%$ in harzburgite). In this assemblage chlorite contributes about $60 \%$ whereas amphibole contains $40 \%$ of the $\mathrm{H}_{2} \mathrm{O}$ bound in hydrous phases. When chlorite is the only hydrous phase, $\mathrm{H}_{2} \mathrm{O}$ contents are $2.1 \mathrm{wt} \%$ in lherzolite (1.0 wt\% in harzburgite). When amphibole is the only stable hydrous phase, $\mathrm{H}_{2} \mathrm{O}$ contents amount to less than $0.5 \mathrm{wt} \%$ in lherzolite $(0.2 \mathrm{wt} \%$ in harzburgite). In chlorite/amphibole assemblages, water contents are higher in fertile than in depleted peridotite, because higher $\mathrm{Na}_{2} \mathrm{O}, \mathrm{CaO}$, and $\mathrm{Al}_{2} \mathrm{O}_{3}$ contents result in larger amounts of amphibole and chlorite.

Serpentine has a predominant role in the water budget of peridotite. When serpentine decomposes, chlorite becomes the dominant hydrous phase. Although amphibole contains ca. $40 \%$ of the $\mathrm{H}_{2} \mathrm{O}$ bound in the $P-T$ domain of chlorite + amphibole, water is not liberated when amphibole decomposes. It is only between $800-850^{\circ} \mathrm{C}$ and the wet solidus (ca. $1000^{\circ} \mathrm{C}$ ) that fluids result from the breakdown of amphibole. The quantity of this fluid is small compared to the fluid resulting from other phases: in lherzolite, the maximum content of amphibole amounts to $19 \mathrm{wt} \%$ (harzburgite $9 \mathrm{wt} \%$ ) contributing a maximum of $0.5 \mathrm{wt} \%$ (harzburgite $0.2 \mathrm{wt} \%$ ) $\mathrm{H}_{2} \mathrm{O}$. Recently, Niida and Green [37] have shown that half of the $25 \%$ amphibole present in a pyrolite at $10-15$ kbar decompose through a continuous reaction before the pressure stability of amphibole is reached at 28-30 kbar. Obviously, in a natural mantle, the reactions of Fig. 5 will take place 
over a temperature-pressure interval. Over a certain temperature-pressure range reactants and products will both be stable and a broad rather than a sharp dehydration signal will result from each particular reaction.

Although phase A has no direct bearing on the formation of arc volcanism, the position of invariant point 4 (Fig. 5) is essential for transporting $\mathrm{H}_{2} \mathrm{O}$ to great depth. When a portion of hydrated peridotitic slab passes a depth of $180 \mathrm{~km}$ at temperatures below ca. $600^{\circ} \mathrm{C}$, phase A forms directly from serpentine and the contained water will not directly recycle into the mantle wedge.

\section{The fate of water released from the subducting lithosphere}

Only a portion of the $\mathrm{H}_{2} \mathrm{O}$ initially contained in the subducting lithosphere will escape from the slab in the depth range suitable for arc magma formation. A large portion of $\mathrm{H}_{2} \mathrm{O}$ will be dehydrated at relatively shallow levels and a small portion will fade into the deeper mantle. In the following we calculate estimates for the different final destinies of subducted water.

\subsection{Oceanic crust}

Blueschists of basaltic origin representing shallow portions of subduction zones (10-20 km) have typically 5-6 wt $\% \mathrm{H}_{2} \mathrm{O}$ bound in hydrous phases. With a $7 \mathrm{~km}$ thick mafic oceanic crust, composed by equal parts of basalt and gabbro, $0.5-0.6 \times 10^{9} \mathrm{~g} \mathrm{H}_{2} \mathrm{O} \mathrm{m}^{-2}$ are bound in the basaltic layer ${ }^{2}$ at shallow depth. Oceanic gabbros are only partially hydrated; with 20-30\% hydration by volume we estimate 0.11$0.18 \times 10^{9} \mathrm{~g} \mathrm{H}_{2} \mathrm{O} \mathrm{m}^{-2}$ for the gabbroic layer. An additional amount of $0.01-0.02 \times 10^{9} \mathrm{~g} \mathrm{H}_{2} \mathrm{O} \mathrm{m}^{-2}$ will be subducted in the sedimentary layer (200-400 $\mathrm{m}$ thick). Some trace elements characteristics for arc volcanism originate mostly from this sedimentary layer; however, its contribution to the $\mathrm{H}_{2} \mathrm{O}$ budget is largely within the error of the estimates for the other layers of the oceanic lithosphere.

\footnotetext{
${ }^{2}$ In the calculations we use a vertical section through the subducting crust with a unit area of $1 \mathrm{~m}^{2}$, thus this number represents the quantity of water in a column of $1 \mathrm{~m}^{2}$.
}

In a vertical section of $1 \mathrm{~m}^{2}$, typical dehydration rates between 20 and $70 \mathrm{~km}$ depth amount to $0.8 \pm 0.2 \times 10^{7} \mathrm{~g} \mathrm{H}_{2} \mathrm{O}$ per kilometre of depth. When the oceanic crust reaches depths of $70-80 \mathrm{~km}$ the resulting lawsonite-eclogites (cold subduction zones) or zoisite-eclogites (relatively warm subduction zones, 'warm' being intended as just below the wet solidus of the oceanic crust) retain 1 or $0.5 \mathrm{wt} \%$ $\mathrm{H}_{2} \mathrm{O}$, i.e. 0.2 or $0.1 \times 10^{9} \mathrm{~g} \mathrm{H}_{2} \mathrm{O} \mathrm{m}^{-2}$, respectively. If lawsonite-eclogites persist to the maximum depth of lawsonite stability (cold subduction zones), 0.02 $0.08 \times 10^{9} \mathrm{~g} \mathrm{H}_{2} \mathrm{O} \mathrm{m}^{-2}$ will descend to $260-280 \mathrm{~km}$ depth and may be lost for arc volcanism (Figs. 7 and 8). At ca. $200 \mathrm{~km}$ depth, typical dehydration rates in the stability field of lawsonite are in the order of $0.05-0.09 \times 10^{7} \mathrm{~g} \mathrm{H}_{2} \mathrm{O}$ per $\mathrm{km}$ depth, i.e. one order of magnitude lower than at shallow levels.

\subsection{Mantle wedge peridotite overlying the oceanic crust}

Here, the only hydrous phase which may persist below the depth of arc volcanism is chlorite (Fig. 7). Thermal models indicate that at depth below the volcanic arc a narrow zone of $1-3 \mathrm{~km}$ may contain chlorite in cold subduction zones yielding a quantity of 0.06 to $0.16 \times 10^{9} \mathrm{~g} \mathrm{H}_{2} \mathrm{O} \mathrm{m}^{-2}$. The rest (60-90\%) of the previously dehydrated 0.4 to $0.6 \times 10^{9} \mathrm{~g} \mathrm{H}_{2} \mathrm{O}$ $\mathrm{m}^{-2}$ from the oceanic crust remains mostly in the cold corner of the mantle wedge and a portion of this $\mathrm{H}_{2} \mathrm{O}$ will give raise to serpentine diapirs.

\subsection{Subducting peridotite underlying the oceanic crust}

With a maximum amphibole content of $19 \mathrm{wt} \%$ in lherzolite the amount of $\mathrm{H}_{2} \mathrm{O}$ bound in amphibole may not exceed $0.5 \mathrm{wt} \%$ of the bulk rock. To achieve a similar bulk $\mathrm{H}_{2} \mathrm{O}$ content due to serpentinization, only $3 \mathrm{wt} \%$ serpentine are necessary. A serpentinization of $3 \%$ causes the density of a lherzolite to decrease from 3.30 to $3.28 \mathrm{~g} / \mathrm{cm}^{3}$, a negligible effect. Even $10 \%$ serpentinization (resulting in $1.3 \mathrm{wt} \% \mathrm{H}_{2} \mathrm{O}$ in the bulk rock) cause only a small decrease in density from 3.30 to $3.23 \mathrm{~g} / \mathrm{cm}^{3}$. Direct information on the extent of serpentinization below the oceanic crust is not available. Serpentine certainly forms at transform faults and fracture zones 

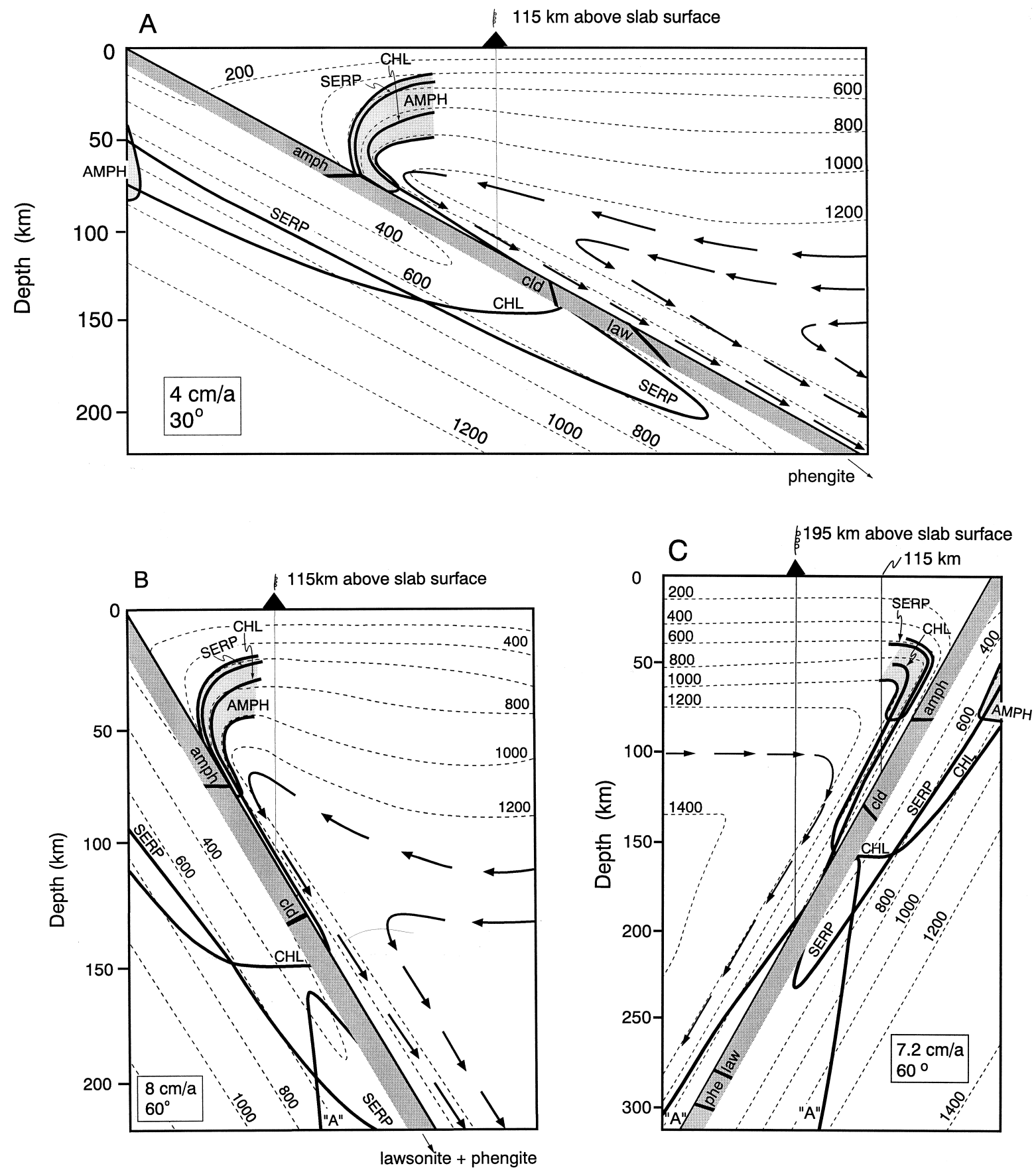

Fig. 7. Stability of hydrous phases for thermal structures with subduction parameters spanning most of the range of modern circum-Pacific subduction zones. Amphibole in peridotite is stable within the light-grey-shaded area (note that at temperatures below $450-500^{\circ} \mathrm{C}$ diopside is stable instead of tremolitic amphibole). Thermal model of [22] (A and B), and of [47] (C). Stippled lines are isotherms and bold arrows indicate flow lines in the mantle wedge. The principal difference between these two models is the much lower corner flow in (C) [47] which leads to a significantly colder peridotite overlying the oceanic crust. The stability limits of hydrous phases in the subducting peridotite underlying the oceanic crust do not imply that these hydrous phases are present deep into the subducting peridotite. Abbreviations as in Figs. 1 and 5; labels in capital letters mark stability boundaries in peridotite. 


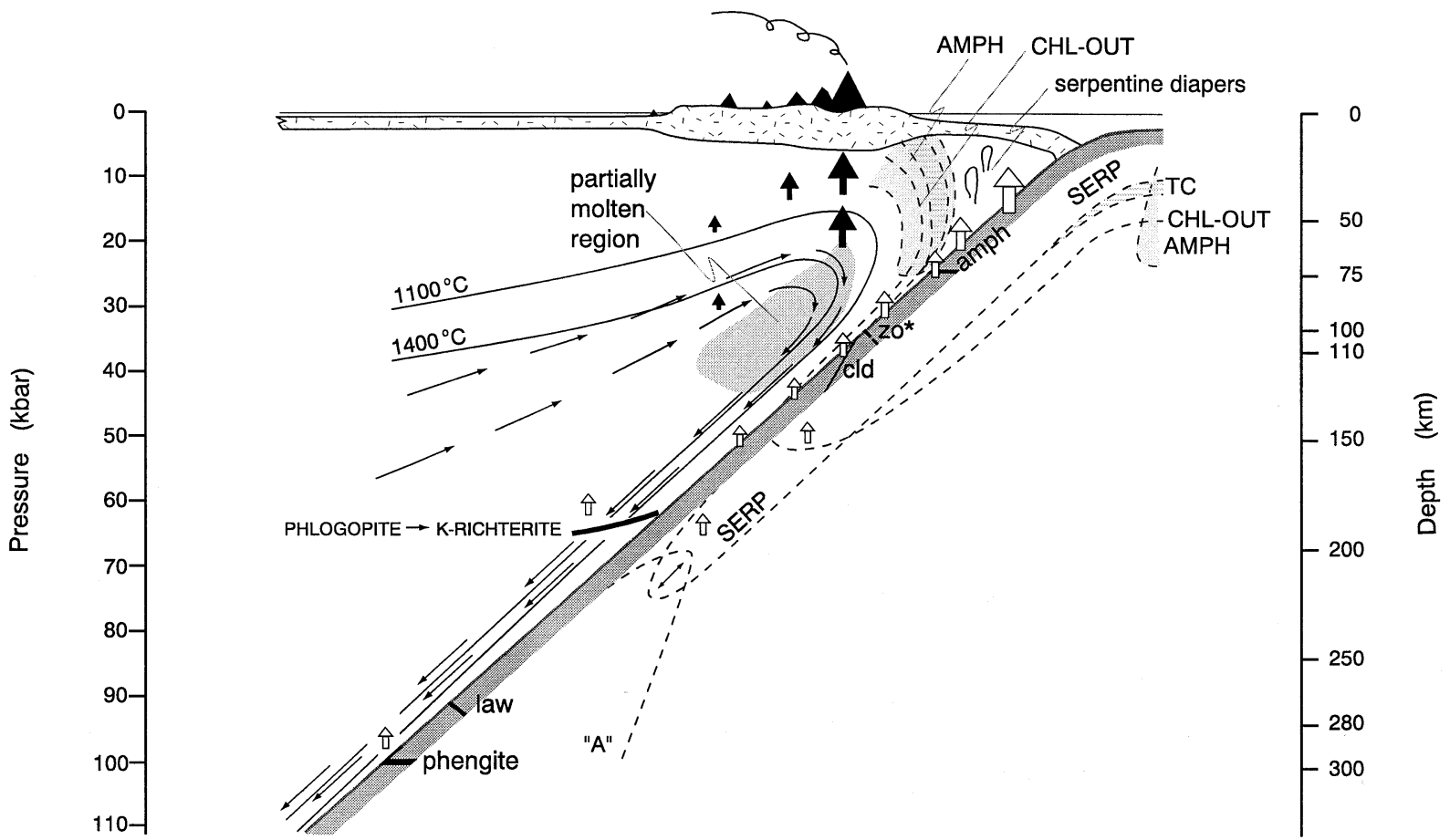

Fig. 8. Model for the formation of the volcanic front. Dehydration from peridotite and oceanic crust occurs at almost any depth to ca. $150-200 \mathrm{~km}$, thus water will be generally available above the subducting lithosphere. The grey region in the mantle wedge will have a significant amount of melt present. The volcanic front forms where the amount of melt is sufficient to mechanically extract and give rise to arc magmatism. Open arrows indicate rise of fluid, short solid arrows indicate rise of melts. Long arrows indicate flow in the mantle wedge. Stippled lines outline stability fields of hydrous phases in peridotite; however, we do not want to imply that peridotite underlying the oceanic crust is fully hydrated. The striped region shows the zone where talc occurs in average peridotite compositions. In some thermal structures (Fig. 7b and c) a portion of the peridotitic lithosphere will be colder than $600^{\circ} \mathrm{C}$ at $62 \mathrm{kbar}$, serpentine will react to phase $\mathrm{A}$ and thus $\mathrm{H}_{2} \mathrm{O}$ will be subducted to large depth. In the oceanic crust, temperatures can be low enough to preserve lawsonite and phengite to their maximum pressure stability; however, at somewhat warmer conditions (slower subduction, shallower angle, younger crust) zoisite $\left(z 0^{*}\right)$ will be the last potassium-free phase to decompose and the top of the oceanic crust (phengite rich sedimentary layer) might melt. Single phase transitions which cause a potassium-rich fluid pulse could be constituted by the pressure breakdown of phengite in oceanic crust and by the phlogopite to K-richterite reaction in previously K-metasomatized mantle.

which subduct together with undisturbed ocean floor. It was estimated that about $20 \%$ of the Pacific Ocean floor are effected by fracture zones [39] and alteration and serpentinization was found to be extensive in ocean basins [40]. We assume a shallow zone of ca. $5 \mathrm{~km}$ depth with an average serpentinization of $10 \%$ which amounts to $0.21 \times 10^{9} \mathrm{~g} \mathrm{H}_{2} \mathrm{O} \mathrm{m}^{-2}$. As an upper limit, this value might be doubled, but then the serpentinized peridotite becomes increasingly buoyant ( $\rho=3.15 \mathrm{~g} / \mathrm{cm}^{3}$ for $20 \%$ serpentinization $)$ and it becomes questionable if such a peridotite might still be able to descend. Less than half of the above value appears to be inconsistent with the degree of serpentinization observed at modern seafloors. Obviously, the hydrated peridotite below the oceanic crust cannot be water-saturated (full serpentinization). Thus, in cold subduction zones where the stability fields of phase $\mathrm{A}$ and serpentine overlap, $\mathrm{H}_{2} \mathrm{O}$ would entirely descend to a large depth and will not be available for arc magmatism. It is only in intermediate to warm subduction zones where fluid will result from serpentine dehydration (Fig. 7). Temperatures in the peridotite of the subducting oceanic lithosphere are lower than in the subducting crust, thus, significant dehydration of this portion of the subducting lithosphere does not take place at shallow levels. At depths where the oceanic crust contains $0.5-2.0 \mathrm{wt} \%$ $\mathrm{H}_{2} \mathrm{O}$, the underlying peridotite might well be a reser- 
voir of water with a mass of $\mathrm{H}_{2} \mathrm{O}$ similar or superior to the $\mathrm{H}_{2} \mathrm{O}$ bound in oceanic crust.

\subsection{The $\mathrm{H}_{2} \mathrm{O}$-budget}

The above calculations show that the oceanic lithosphere contains about $0.71-1.08 \times 10^{9} \mathrm{~g} \mathrm{H}_{2} \mathrm{O}$ $\mathrm{m}^{-2}$ at $20 \mathrm{~km}$ depth. Both the hydration state of the unmetamorphosed oceanic crust and the early diagenetic processes (e.g. expulsion of pore water [41]) in and below the accretionary prism are extremely difficult to quantify. Thus, we prefer to define the 'input' into subduction zones through the state of the oceanic lithosphere at $20 \mathrm{~km}$ depth. Our estimate is higher than the $0.3 \times 10^{9} \mathrm{~g} \mathrm{H}_{2} \mathrm{O} \mathrm{m} \mathrm{m}^{-2}$ of Peacock [42] which did not consider serpentinization below the oceanic crust and based his estimate on the few DSDP drill holes which perforated into the crystalline oceanic crust. It was pointed out by Bebout [41] that this latter procedure may significantly underestimate the volatile content of subducted crust.

The summation of the above estimates yield the following picture for the amount of $\mathrm{H}_{2} \mathrm{O}$ available for arc volcanism. In cold subduction zones, 0.12 to $0.18 \times 10^{9} \mathrm{~g} \mathrm{H}_{2} \mathrm{O} \mathrm{m}^{-2}$ will rise from the oceanic crust and 0.06 to $0.16 \times 10^{9} \mathrm{~g} \mathrm{H}_{2} \mathrm{O} \mathrm{m}^{-2}$ will rise from the peridotitic layer above the oceanic crust. Thus, the total amounts to 0.18 to $0.34 \times 10^{9} \mathrm{~g} \mathrm{H}_{2} \mathrm{O} \mathrm{m}{ }^{-2}$ since no dehydration occurs below the oceanic crust. In intermediate to warm subduction zones, about $0.1 \times 10^{9} \mathrm{~g} \mathrm{H}_{2} \mathrm{O} \mathrm{m}^{-2}$ will rise from the oceanic crust and roughly 0.1 to $0.3 \times 10^{9} \mathrm{~g} \mathrm{H}_{2} \mathrm{O} \mathrm{m}^{-2}$ from the peridotite below the oceanic crust. Thus, the total amounts to 0.2 to $0.4 \times 10^{9} \mathrm{~g} \mathrm{H}_{2} \mathrm{O} \mathrm{m}^{-2}$ since no dehydration occurs above the oceanic crust. It follows that between 18 and $37 \%$ of the 0.7 to $1.1 \times 10^{9} \mathrm{~g}$ $\mathrm{H}_{2} \mathrm{O} \mathrm{m}^{-2}$ present at $10-20 \mathrm{~km}$ depth are available for the generation of arc magmas. This portion of $\mathrm{H}_{2} \mathrm{O}$ will rise into the mantle wedge in the depth interval between 80 and $150 \mathrm{~km}$. An interesting feature of the above estimate is that there is no principal difference for the recycling rate of water in the volcanic arc between a cold and a warm subduction zone ('warm' always being intended as temperatures of the oceanic crust just below its solidus). The above result is higher than estimates that globally $10 \%$ to $20 \%$ of the subducted water is expelled via arc magmatism $[42,43]$. However, not all of the water dehydrated below the arc region will appear at the surface, one portion of the dehydrated water will remain in the mantle wedge.

The above estimates also yield that $30-70 \%$ or 0.25 to $0.7 \times 10^{9} \mathrm{~g} \mathrm{H}_{2} \mathrm{O} \mathrm{m} \mathrm{m}^{-2}$ of the initially subducted $\mathrm{H}_{2} \mathrm{O}$ will be released to the cold corner of the mantle wedge where serpentine is stable. According to the thermal models of Furukawa [22] this region has cross-sections of ca. $3.1 \times 10^{9} \mathrm{~m}^{2}$ for a $30^{\circ}$ subduction angle and of 0.7 to $0.9 \times 10^{9} \mathrm{~m}^{2}$ for a $60^{\circ}$ subduction angle $(4-8 \mathrm{~cm} /$ a subduction rates). Full serpentinization (and chloritization) of the cold corner requires about $0.2 \times 10^{6} \mathrm{~g} \mathrm{H}_{2} \mathrm{O} \mathrm{m}^{-3}$, the bulk rock density would be $2.88 \mathrm{~g} / \mathrm{cm}^{3}$. For a stationary cold corner, full serpentinization (and chloritization) would be achieved after subduction of $570-790 \mathrm{~km}$ slab for a $30^{\circ}$ subduction angle and $130-220 \mathrm{~km}$ slab for a $60^{\circ}$ subduction angle.

\section{Consequences of the experimentally based water budget for the formation of the volcanic front}

In the following we discuss models for the formation of volcanic fronts in the light of our water budget. We focus exclusively on arcs where parent magmas form from melting of the mantle wedge and do not discuss slab-derived melts. Such direct melting of the oceanic crust (for models see Ref. [44]) and subsequent adakitic magmatism may only occur when very hot young crust is subducted and is rare on the modern Earth [45].

\section{1. 'Single phase dehydration models' and the role of amphibole for arc magmatism}

Many models for the formation of arc magmatism have been proposed in the last two decades. Some of these models involve a multistage process which evokes dehydration of the slab at a relatively shallow depth and intermediate storage of $\mathrm{H}_{2} \mathrm{O}$ (and trace elements deriving from the subducted slab) in a single, key hydrous phase in the mantle wedge. Subsequently it is either proposed that the down-dragged mantle wedge dehydrates and melting occurs above this dehydration zone or that melting of the mantle wedge occurs on the wet solidus of peridotite. 
A number of hydrous phases have been called on to explain such transient storage of $\mathrm{H}_{2} \mathrm{O}$ and of other 'metasomatizing components' within the mantle wedge $[30,46,47]$.

Tatsumi [2,46] and Davies and Stevenson [47] ascribe the distribution maximum of volcanic fronts to the amphibole breakdown in peridotite. Tatsumi assigned the formation of volcanic front to melting within a hydrous column forming directly above amphibole dehydration in peridotite at ca. $110 \mathrm{~km}$ depth. Davies and Stevenson [47] evoked a mechanism of lateral transport of water in the mantle wedge. They propose that amphibole dehydrates at ca. $90 \mathrm{~km}$ depth but the rising fluid (or melts) rehydrates the convecting mantle wedge and again forms amphibole. Through such a stepwise process water was thought to be transported laterally within the hot wedge. Both these amphibole-based models are in disagreement with available experimental and geochemical constraints.

(1) As previously discussed, the breakdown of calcic amphibole in peridotite occurs, as a function of peridotite composition, between 22 and $30 \mathrm{kbar}$, i.e. between 65 and $90 \mathrm{~km}$ depth. A lateral transport mechanism [47] is only possible for a limited horizontal distance because amphibole melts between the 1000 and $1100^{\circ} \mathrm{C}$ isotherm in the mantle wedge [48] to form high $\mathrm{Mg}$-andesites. Although such magma compositions occur in arcs, they are not candidates for primitive arc magmas. The most primitive magmas in arcs are basalts to picritic basalts. For their generation, temperatures of $1300-1350^{\circ} \mathrm{C}$ are necessary ([49-51], fig. 5.6 in [46] and references therein). Thus, even though this mechanism is possible, amphibole falls short in transporting laterally water into the source region of basaltic magmas (Fig. 7).

(2) Even when stable, amphibole contributes moderately to the water budget. It follows from the mass balance calculations that amphibole has a relatively small contribution to the water budget of peridotite $\left(0.2-0.5 \mathrm{wt} \% \mathrm{H}_{2} \mathrm{O}\right.$ of the bulk rock) with respect to the other hydrous phases. Furthermore it decomposes through continuous reactions [37] and its final breakdown depth is extremely sensible to bulk composition.

(3) Gill and Williams [52] described that about $60 \%$ of island arc magmas have U-Th disequilibrium due to U-excess. This U-excess is believed to result from dehydration of the oceanic crust, the preservation of U-Th disequilibrium thus constrains dehydration of the slab to take place less than 350,000 years before eruption of arc magmas. For different arcs, the time interval between U-addition to the magma and eruption was determined to be less than 20,000 to 200,000 years $([4,53]$ and references therein). The additional time required for 'lateral transport' [47] or 'simple downdrag' [46] of $\mathrm{H}_{2} \mathrm{O}$ through amphibole can be calculated from subduction geometries and velocity fields in the wedge. At high subduction rates of $10 \mathrm{~cm} / \mathrm{a}$ and maintaining this high velocity between subducted crust and melting region in the mantle wedge, 460,000 years $\left(60^{\circ}\right.$ angle of subduction) to 700,000 years $\left(30^{\circ}\right.$ angle of subduction) are necessary for $\mathrm{H}_{2} \mathrm{O}$ transport through amphibole to a position below the volcanic front. Because the convection velocity in the mantle wedge is much slower than the velocity of the subducted lithosphere, realistic time spans for such transport mechanisms would be 1.5 to 3 times longer (velocity fields from [22,47]) and thus would largely exceed 350,000 years.

We conclude that the role of amphibole is not outstanding with respect to other hydrous phases. Amphibole cannot constitute 'the' fluid source situated below the volcanic front.

\subsection{Towards a 'continuous dehydration model'}

The phase petrological data indicate that some fluid rises from the subducting slab and hydrates a portion of the overlying mantle wedge at almost any depth to ca. $150-200 \mathrm{~km}$. Phase relationships in mafic and ultramafic lithologies reveal that, at a given depth, several hydrous phases will decompose through either discontinuous or continuous reactions. Since temperature gradients are high (up to $50^{\circ} \mathrm{C} / \mathrm{km}$ ) close to the slab surface, most dehydration reactions will be smeared out over a significant depth interval instead of taking place at a distinct depth. Further broadening of the dehydration signal results from (1) local/vertical inhomogeneities in bulk composition cause different solid phase compositions and consequently dehydration reactions take place at slightly varying $P-T$ conditions, and (2) uneven $\mathrm{H}_{2} \mathrm{O}$ distribution in coronitic metagabbros and metaperidotites. As a consequence, sections through 
natural subducting lithosphere will have an even more continuous dehydration signal than indicated by our investigated basalt $-\mathrm{H}_{2} \mathrm{O}$ and peridotite $-\mathrm{H}_{2} \mathrm{O}$ systems. It should be noted that, independent from phase equilibria data, several recent geochemical studies on modern arcs $[6,54,55]$ equally propose a continuous dehydration of the subducting lithosphere on the basis of trace element and isotopic data.

Dehydration at low pressures is almost entirely due to potassium-free phases, whereas at pressures above $30 \mathrm{kbar}$, phengite becomes more and more important. The extensive pressure stability of phengite $[9,26]$ indicates that it is more difficult to recycle potassium from the slab than descending potassium to the breakdown depth of phengite $(270-300 \mathrm{~km})$. Two continuous processes will allow to recover a portion of the potassium (and related elements). (1) A continuous formation of K-clinopyroxene from phengite liberates water (and thus hydrophile elements such as potassium). This reaction becomes efficient only above 50 kbar. (2) Potassium loss in the oceanic sediments and basalts could be obtained by leaching of hydrophile elements by fluids rising from the lower part of the oceanic crust or the hydrated subducting peridotite through the sedimentary layer.

Consequently $\mathrm{H}_{2} \mathrm{O}$-rich fluids with a variable geochemical signal will be generally available above subducting lithosphere to at least $150-200 \mathrm{~km}$ depth (Fig. 8).

The next question to answer is 'where does the volcanic front form?'. Kushiro [49] suggested that a significant amount of melt forms and collects at the trench-nearside of the partially molten region and deduced that the volcanic front simply forms above the trench-nearest partially molten mantle wedge. Temperatures for attainment of melting in the mantle wedge below volcanic fronts can be deduced from primary arc magmas. Primitive arc magmas from the Earth's surface and experiments on such magmas (which must be in equilibrium with mantle compositions) indicate mantle wedge temperatures of 1300$1350^{\circ} \mathrm{C}[46,49-51]$. Although the quantity of primitive magmas in arcs is small, the very existence of these magmas shows that such temperatures exist below the volcanic arc. Thus, most likely the temperature necessary for mechanical extraction of parental arc magmas is achieved at $1300-1350^{\circ} \mathrm{C}$. Therefore the location of the volcanic front is expected to de- pend mostly on the position of the $1300^{\circ} \mathrm{C}$ isotherm and (Fig. 8) on the individual subduction parameters which determine the mantle wedge structure.

Unfortunately only few models deal in detail with the concurrent solution of both thermal and mechanical properties of the mantle wedge. The geometry of velocity fields in the wedge and therefore the evolution of the thermal structure close to the 'magic corner' mostly depend on the degree of coupling between the subducting slab and the wedge, on mantle wedge viscosity, and on the thickness of the rigid mechanical lithosphere (compare models in $[22,47]$ and [56]). The attainment of mantle wedge temperatures of $1300^{\circ} \mathrm{C}$ below volcanic arcs are obtained when a vigorous, convective return flow is enhanced either by decoupling and/or progressive thinning of the mechanical lithosphere. A number of other parameters such as convergence rate, dip angle of the slab, age of the slab and initial temperature profile obviously play a major role in determining the magnitude of such return flow [56]. Without a significant corner flow below volcanic fronts mantle wedge temperatures would rapidly cool down and arc magmatism would cease. Seismic tomography and heat flow distribution in Japan are among the most striking evidences which support that such induced flow drives hotter isotherms into the corner ([22,56] and references therein).

Thus, a model where the location of melting in the mantle wedge determines the position of the volcanic front [49] would be consistent with natural observations.

\section{Acknowledgements}

We would like to thank O. Sigmarsson and P. Ulmer for discussions. The first version of the manuscript was prepared as M.W. Schmidt was a guest at Tokyo Institute of Technology. Many thanks for enlightening discussions with S. Maruyama. [CL] [FA]

\section{References}

[1] J. Gill, Orogenic Andesites and Plate Tectonics, Springer, New York, 1980, 390 pp. 
[2] Y. Tatsumi, Formation of the volcanic front in subduction zones, Geophys. Res. Lett. 17 (1986) 717-720.

[3] J.D. Morris, W.P. Leemann, F. Tera, The subducted component in island arc lavas: constraints from $\mathrm{Be}$ isotopes and B-Be systematics, Nature 344 (1990) 31-36.

[4] O. Sigmarsson, M. Condomines, J.D. Morris, R.S. Harmon, Uranium and ${ }^{10} \mathrm{Be}$ enrichments by fluids in the Andean arc magmas, Nature 346 (1990) 163-165.

[5] T. Plank, C.H. Langmuir, Tracing trace elements from sediment input to volcanic output at subduction zones, Nature 362 (1993) 739-743.

[6] T. Ishikawa, E. Nakamura, Origin of the slab component an arc lavas from across-arc variation of $\mathrm{B}$ and $\mathrm{Pb}$ isotopes, Nature 370 (1994) 205-208.

[7] A.V. Sobolev, M. Chaussidon, $\mathrm{H}_{2} \mathrm{O}$ concentrations in primary melts from supra-subduction zones and mid-ocean ridges: implications for $\mathrm{H}_{2} \mathrm{O}$ storage and recycling in the mantle, Earth Planet. Sci. Lett. 137 (1996) 45-55.

[8] S. Poli, The amphibolite-eclogite transformation: an experimental study on basalt, Am. J. Sci. 293 (1993) 10611107.

[9] M.W. Schmidt, Experimental constraints on recycling of potassium from subducted oceanic crust, Science 272 (1996) 1927-1930.

[10] S. Poli, M.W. Schmidt, $\mathrm{H}_{2} \mathrm{O}$ transport and release in subduction zones: experimental constraints on basaltic and andesitic systems, J. Geophys. Res. 100 (1995) 2229922314.

[11] D.C. Rubie, S. Karato, H. Yan, H.St.C. O'Neill, Low differential stress and controlled chemical environment in multianvil high pressure devices, Phys. Chem. Miner. 20 (1993) 315-322.

[12] M.J. Apted, J.G. Liou, Phase relations among greenschist, epidote-amphibolite, and amphibolite in a basaltic system, Am. J. Sci. A 283 (1983) 328-354.

[13] A.R. Pawley, J.R. Holloway, Water sources for subduction zone volcanism: new experimental constraints, Science 260 (1993) 664-667.

[14] B. Messiga, M. Scambelluri, Retrograde P-T-t path for the Voltri Massif eclogites (Ligurian Alps, Italy): some tectonic implications, J. Metamorph. Geol. 9 (1991) 93-109.

[15] A.I. Okay, Mineralogy, petrology, and phase relations of glaucophane-lawsonite zone blueschists the Tavsanh region, Northwest Turkey, Contrib. Mineral. Petrol. 72 (1980) 243255.

[16] B.C. Storey, A.W. Meneilly, Petrogenesis of metamorphic rocks with a subduction-accretion terrane, Signey Island, South Orkney Islands, J. Metamorph. Geol. 3 (1985) 2142.

[17] S.P. Thursten, Structure, petrology, and metamorphic history of the Nome group blueschist terrane, Salmon Lake area, Seward Peninsula, Alaska, Geol. Soc. Am. Bull. 96 (1985) 600-617.

[18] S.W. Faryad, Phase petrology and P-T-conditions of mafic blueschists from the Meliata unit, West Carpathians, Slovakia, J. Metamorph. Geol. 13 (1995) 701-714.

[19] R.Y. Zhang, J.G. Liou, B.L. Coney, Talc-, magnesite-, and Ti-clinohumite-bearing ultrahigh-pressure meta-mafic and ultramafic complex in the Dabie Mountains, China, J. Petrol. 36 (1995) 1011-1037.

[20] S.M. Peacock, The importance of blueschist $\rightarrow$ eclogite dehydration reactions in subducting oceanic crust, Geol. Soc. Am. Bull. 105 (1993) 684-694.

[21] J.G. Liou, S. Maruyama, M. Cho, Phase equilibria and mineral parageneses of metabasites in low-grade metamorphism, Mineral. Mag. 49 (1985) 321-333.

[22] Y. Furukawa, Magmatic processes under arcs and formation of the volcanic front, J. Geophys. Res. 98 (1993) 83098319.

[23] U. Pognante, Petrological constraints on the eclogite- and blueschist-facies metamorphism and $\mathrm{P}-\mathrm{T}-\mathrm{t}$ paths in the Western Alps, J. Metamorph. Geol. 9 (1991) 5-17.

[24] G.T. Nichols, P.J. Wyllie, C.R. Stern, Subduction zone melting of pelagic sediments constrained by melting experiments, Nature 371 (1994) 785-788.

[25] N. Benciolini, S. Poli, M. Valle, High pressure phase relationships in metapelites: an experimental study , Terra 8, Abstr. Suppl. 1 (1996) 7.

[26] K.J. Domanik, J.R. Holloway, The stability and composition of phengitic muscovite and associated phases from 5.5 to $11 \mathrm{GPa}$ : implications for deeply subducted sediments, Geochim. Cosmochim. Acta 60 (1996) 4133-4150.

[27] B.W. Evans, W. Johannes, H. Oterdoom, V. Trommsdorff, Stability of chrysotile and antigorite in the serpentine multisystem, Schweiz. Mineral. Petrogr. Mitt. 50 (1976) 481492.

[28] P. Ulmer, V. Trommsdorff, Serpentine stability to mantle depths and subduction related magmatism, Science 268 (1995) 858-861.

[29] B.O. Mysen, A.L. Boettcher, Melting of hydrous mantle, I: Phase relations of natural peridotite at high pressures and temperatures with controlled activities of water, carbon dioxide, and hydrogen, J. Petrol. 16 (1975) 520-548.

[30] K. Bose, J. Ganguly, Experimental and theoretical studies of the stabilities of talc, antigorite and phase A at high pressures with application to subduction processes, Earth Planet. Sci. Lett. 136 (1995) 109-121.

[31] D.M. Jenkins, J.V. Chernovsky, Phase equilibria and crystallochemical properties of Mg-chlorite, Am. Mineral. 71 (1986) 924-936.

[32] R.W. Luth, Is phase A relevant to the Earth's mantle? Geochim. Cosmochim. Acta 59 (1995) 679-682.

[33] A.R. Pawley, High pressure stability of chlorite: a source of $\mathrm{H}_{2} \mathrm{O}$ for subduction zone magmatism , Terra 8, Abstr. Suppl. 1 (1996) 50.

[34] T. Fockenberg, New experimental results up to $100 \mathrm{kbar}$ in the system $\mathrm{MgO}-\mathrm{Al}_{2} \mathrm{O}_{3}-\mathrm{SiO}_{2}-\mathrm{H}_{2} \mathrm{O}$ (MASH): preliminary stability fields of chlorite, chloritoid, staurolite, $\mathrm{MgMgAl}-$ pumpellyite, and pyrope, Bochumer Geol. Geotech. Arb. 44 (1995) 39-44.

[35] G.L. Millholen, A.J. Irving, P.J. Wyllie, Melting interval of peridotite with 5.7 per cent water to 30 kilobars, J. Geol. 82 (1974) 575-587.

[36] D.H. Green, Experimental melting studies on a model upper 
mantle composition at high pressure under water-saturated and water-undersaturated conditions, Earth Planet. Sci. Lett. 19 (1973) 37-53.

[37] K. Niida, D.H. Green, Stability and chemical composition of pargasitic amphiboles in MORB pyrolite under upper mantle conditions, Earth Planet. Sci. Lett. (in press).

[38] T.J.B. Holland, R. Powell, An enlarged and updated internally consistent thermodynamic dataset with uncertainties and correlations: the system $\mathrm{K}_{2} \mathrm{O}-\mathrm{Na}_{2} \mathrm{O}-\mathrm{CaO}-\mathrm{MgO}-$ $\mathrm{MnO}-\mathrm{FeO}-\mathrm{Fe}_{2} \mathrm{O}_{3}-\mathrm{Al}_{2} \mathrm{O}_{3}-\mathrm{TiO}_{2}-\mathrm{SiO}_{2}-\mathrm{C}-\mathrm{H}_{2}-\mathrm{O}_{2}$, J. Metamorph. Geol. 8 (1990) 89-124.

[39] J. Mammerickx, Large scale undersea features on the northeast Pacific, in: E.L. Winterer, D.M. Hussong, R.W. Decker (Eds.), The Eastern Pacific Ocean and Hawaii, The Geology of North America, Vol. N, Geol. Soc. Am., 1989, pp. 5-13.

[40] T. Juteau, M. Cannat, Y. Lagabrielle, Serpentinized peridotites in the upper oceanic crust away from transform zones: a comparison of the results of previous DSDP and ODP legs, Proc. ODP, Sci. Results 106 (1990) 303-312.

[41] G.E. Bebout, Volatile transfer and recycling at convergent margins: mass-balance and insights from high-P/T metamorphic rocks (overview), in: G.E. Bebout, D.W. Scholl, S.H. Kirby, J.P. Platt (Eds.), Subduction, Top to the Bottom, Am. Geophys. Union, Geophys. Monogr. 96.

[42] S.M. Peacock, Fluid processes in subduction zones, Science 248, 329-337.

[43] E. Ito, H. Harris, A.T. Anderson, Alteration of oceanic crust and geologic cycling of chlorine and water, Geochim. Cosmochim. Acta 47 (1983) 1613-1624.

[44] P.J. Wyllie, Constraints imposed by experimental petrology on possible and impossible magma sources and products, Philos. Trans. R. Soc. London A 310 (1984) 439-456.

[45] H. Martin, Effect of steeper Archean geothermal gradient on geochemistry of subduction-zone magmas, Geology 14 (1986) 753-756.

[46] Y. Tatsumi, S. Eggins, Subduction Zone Magmatism, Blackwell, Oxford, 1995, $211 \mathrm{pp}$.

[47] J.H. Davies, D.J. Stevenson, Physical model for the source region of subduction zone volatiles, J. Geophys. Res. 97 (1992) 2037-2070.
[48] K. Hirose, Melting experiments on lherzolite KLB-1 under hydrous conditions and generation of high-magnesian andesite melts, Geology, Jan. issue 1997.

[49] I. Kushiro, A petrological model of the mantle wedge and lower crust in the Japanese island arcs, In: B.O. Mysen (Ed.), Magmatic Processes: Physicochemical Principles, Geochem. Soc. Spec. Publ. 1 (1987) 165-181.

[50] P. Ulmer, High-pressure phase equilibria of a calc-alkaline picro-basalt: implications for the genesis of calc-alkaline magmas, Carnegie Inst. Washington Yearb. 88 (1988) 28 35.

[51] E. Takahashi, T. Shimazaki, Y. Tsuzaki, H. Yoshida, Melting study of a peridotite KLB-1 to $6.5 \mathrm{GPa}$, and the origin of basaltic magmas, Philos. Trans. R. Soc. London A 342 (1993) 105-120.

[52] J.B. Gill, R.W. Williams, Th isotope and U-series studies of subduction-related volcanic rocks, Geochim. Cosmochim. Acta 54 (1990) 1427-1442.

[53] T. Elliot, T. Plank, A. Zindler, Element transport from slab to volcanic front at the Mariana arc, J. Geophys. Res. 102 (1997) 14991-15019.

[54] T. Shibata, E. Nakamura, Across-arc variations of isotope and trace element compositions from Quaternary basaltic volcanic rocks in northeastern Japan: implications for interaction between subducted oceanic slab and mantle wedge, J. Geophys. Res. 102 (1997) 8051-8064.

[55] T. Ishikawa, F. Tera, Distribution and composition of slab derived fluid in the Kurile mantle wedge: constraints from across-arc and along-arc variations of $\mathrm{B} / \mathrm{Nb}$ and $\mathrm{B}$ isotopes, Earth Planet. Sci. Lett. (in press).

[56] C. Kincaid, I.S. Sacks, Thermal and dynamical evolution of the upper mantle in subduction zones, J. Geophys. Res. 102 (1997) 12295-12315.

[57] G.C. Brown, A.E. Musset, The Inaccessible Earth, an Integrated View of Its Structure and Composition, Chapman and Hall, London, 1993.

[58] A.E. Ringwood, The chemical composition and origin of the Earth, in: P.M. Hurley (Ed.), Advances in Earth Sciences, M.I.T. Press, Cambridge, MA, 1966, pp. 287-355. 